3D2p1 4 Leuconostioc pesenteroides NRRL B-512P株のア゙キストラ ンシュクラーゼ検成的变買梾について ○水谷尚子、山田真唐、高山揵一郎、正田誠

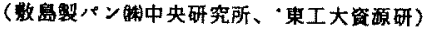

(目的) 立 mesenteroides NRRL B-512F楼加生産する゙゙キストラン

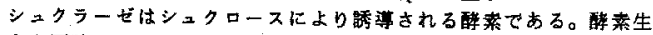
产と同時にシュクロース加ら粘性の高いデキストラン加生成するた

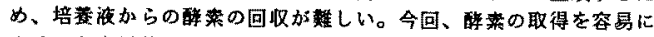
することを目的として、シュクロース以外の稹を炭卖願とした時に

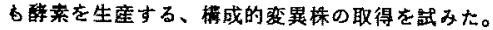

(方法・結果) NTG 処理 Lた L mesenteroi des NRRL B-512F标をグ ルコースを炭素碩とした寒天培地上て生有させた後、テトラサイク リンを含しシュクロース寒天を重既し、25午で6時䦚放置した。 ロニーの周りにデキストランを生成した約750株からスクリーニン

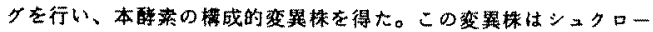
ス培地以外に、タルコース、フラクトース、マルトースの単独また

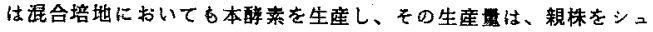
クロース培地で培养したときの2〜3陪を示した。また、媇株と变穓

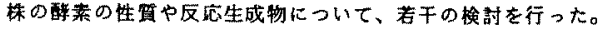

3D2p15 Bacillus sp. DK-39株の生産するし-アロスレオニンアルドラー 七一精製と諸性筫一

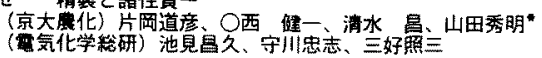

【目的】演者らはスレオニンの4 種の異性体のうちし-アロスレオニンを 立体選択的にグリシンとアセトアルデヒドに分解するし・アロスレオニン アルドラーゼをBacillus sp. DK-39株に見い出した”。今回、本菌より

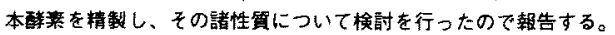

【方法・結果】本菌の無細胞抽出液より硫安分画、DEAE-Sephacel、 Phenyl-Sepharose. Hydroxyapatite, Sephacryl S-300HRの各種クロマ

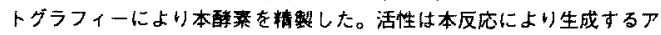

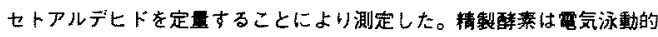
に均一であり、SDS-PAGEによりサブユニットの分子豊は約38,000、

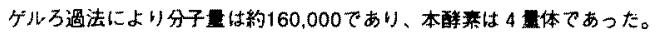

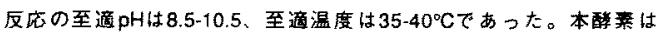
pH6-9で安定であり、15分問の熱题理で $35^{\circ} \mathrm{C}$ で安定であった。本醉

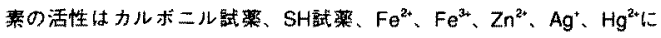

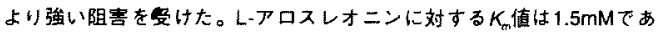
つた。 *関西大学工学部

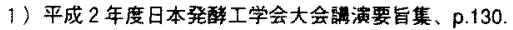

3D2P16 Fusarium oxysporumの生産するアルドラクトナーセに含 まれる糖销の役割の解明 (2) 精鎖梅造と結合部位

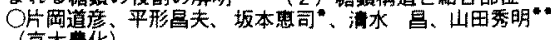
(京大鹿化)

演者らはFusarium oxysporum AKU 3702が種タのラクトン化合物に 作用する新規なうクトナーゼを生痤することを見出しその硣性宽を明ら

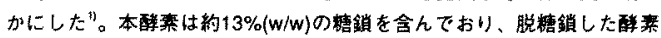
と性筫を比較した結果、本醉慗において栯镍は安定性に大きく寄与して いることが明らかとなったれ。今回は、本醉慗に含まれる数銷の柫造解 明と結合部位の特定について検尌した結果を報告する。

本醉素をヒドラジン分解した後、粕鎖をピリジルアミノ(PA)化し、 PA化湅銷を得た。ODS-シリカおよびアミドーシリカカラムによる分析

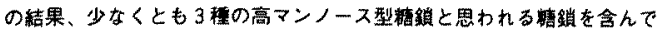
いることが判明した。また、本醭をりジルエンドベブチダーぜで消化 後、精銷の結合したベブチドを精製した結果、数本の䌅ベブド在得た。 これらに対してN-glycanase処理を行って精銷を切け出し、そのアミノ

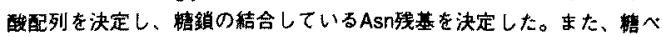
フチトににつてもヒトララジン分解、PA化を行い、結合精制の分析を行 つた。 ・宾士楽品工菜(株)、“関西大学工学部

"S. Shimizu ot al., Eur. 4 Biochem. 209, 383-390 (1992).

${ }^{2}$ 清水昌他、平成 4 年度日本生物工学会大会满漠要旨集、0.115.
3D2p17 Bacillus megaterium PYR2910のピロールー2-カルボン酰炭酸

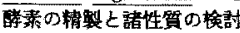

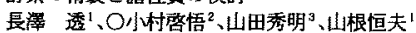
（各大食工化、池田糖化工業、京大農化 ${ }^{3}$ )

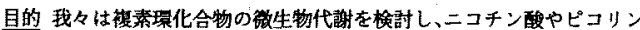
酸のような含空素模素理化合物の销生物分解はまずピリシンン理の水酸化 反応に始まることを明らかにした。ピロールー2ーカルボン酸の微生物分解 もビロール瓄への水酸化店によって開始される上予想していたが、害 祭、本化合物はます脱岸酸反応によって代唧されることを見いだした。我 々はBacillus megateriしmのピロールー2-カルボン酸の脱岩酸醇素に注目 し、本醉莱の䊑製之諸性質の检討を試みた。

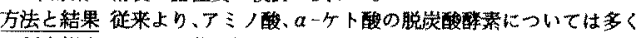

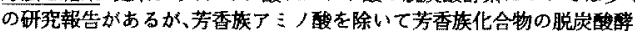

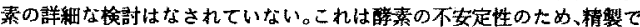
きない上報告されている。ピロールー2ーカルボン酸の分解统化菌Bacillus

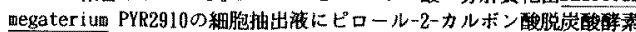
活性が見い大さされるが、本磁素もやはり希釈や透析に上って速やかに活 性を無くする。しかし、酸酸などの有機酸の添加によって活性が100\%回得

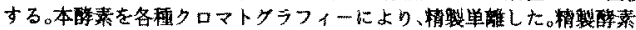
はコファクターとしてビリドキザルリン酩やチアミンビロリン酸を要求 世す、活性発現に酷酸等の有機酸を必要とする新しい現象を示した。また 本硣素治炭酸ナトリウムの存在下、ピロールからピロールー2-カルボン酸

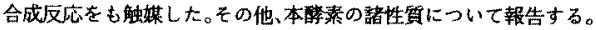

3D2p1 8 Arthrobacier sp. MCl2612のマレートヒドラターぜに関する

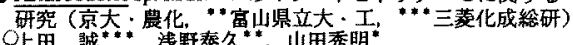

1）目的 我々はすでにArthrobacter sp. MCI2612の休止菌体反応 によりマレイン酸からD-リンコ酸が效率良く生産されることを示

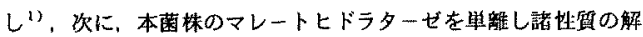

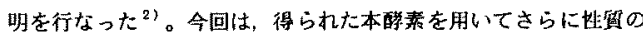
検㣙を行なった。

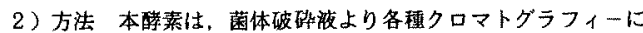

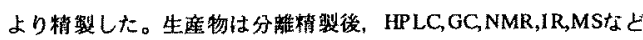
により同定した。

3) 結果 種々の有機酸による反応の阻害を調へた。本醅菜はマ レイン酸の買性体のフマル酸による阻害はなかったか， L(+)-,D(-) 一,血eso-酒石酸、Lーリンコ酸、才キサロ酿酸、アセチレンジカルボ ン酸など、いくつかのジカルボン酸により阻書された。また，本 蟀菜はシトラコン酸と反応し，R(-)シトラマル酸を生成すること が明かとなった。現：関西大 I

" 山田ら；1991年度日本発醇工学会大会潇演要旨集p223

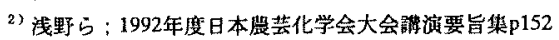

3D2p19

獾生物によるマレイン酸からのD-リンゴ酸の生産

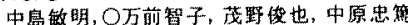

(筑波大・応生化)

マレイン酸はフマル酸しcis-trans 幾何異栍体の関係におり、比較的安

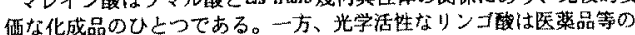
合成において有用である。マレイン酸からDーリンコ酸を効率よく 生産する諴生物について休止菌体を用いて娭索を行なった結果、

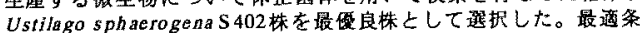
件下でのD-リンす酸生等盟は、反応 48 時間において $40.8 \mathrm{mg} / \mathrm{ml}$

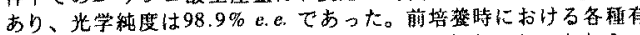
搭酸の添加効果を检討したところ全く效果が無かったことから、

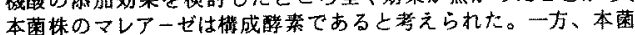

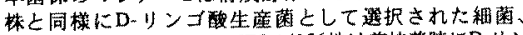

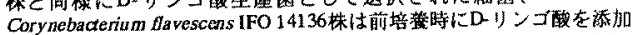

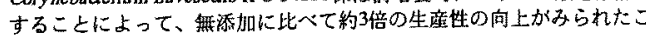

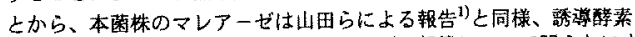
であると考えられた。雨菌株のマレアーゼの相避について明らかにす

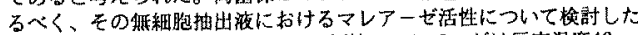
結果、をれをれC flavescensIFO14136姝のマレアーゼは反応温度40

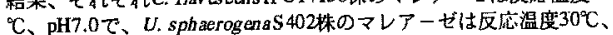

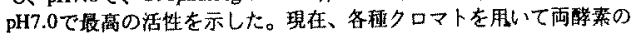
梢製を行なっている。

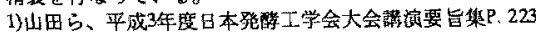


3D2p20醉母クルタチオン アートランスフェラーゼの局在性について

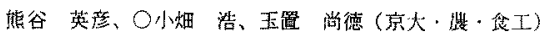

（目的）グルタチオンSートランスフェラーゼ（ＧST）は、生

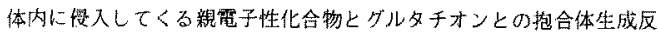

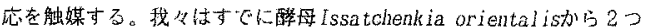
のGSTアイソザイムGST Y-1，Y-2を精製し、Y-2についてはクロ

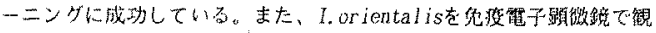
祭したとごろ䋥胞壁周辺にGS T Y-2が局在していることが明らかに

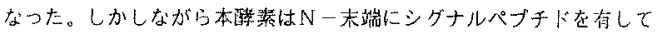

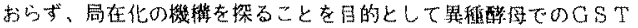
Y-2の発現を試武た。

（方法および結果）ＧＳＴＹ-20ＣDNAを、グリセルアルデヒ

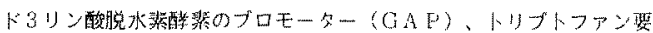

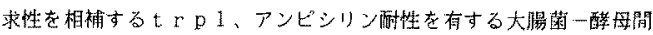
のシャトルヘクターに組み込んだ。トリプトファン要求性である醉母

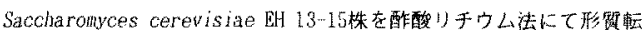

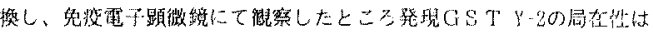

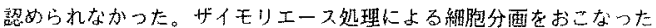

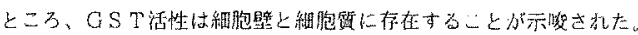

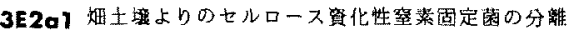 内野不二(名大为化)}

1。目的演者等はこれまでにセルロース資化性窒素固定菌の祡索

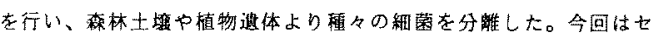

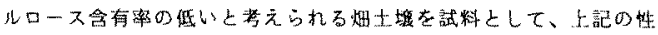
筫を有する細菌の分睢を試みた。

2. 万法及び結果 7 地点の畑地を任意に選び、その土塻在試料上 して、セルロースを炭絭愿とするN-deficient semisolid mediumを 用いて集積し、nitrogenase(アセチレン透元) 活性を有する細菌の

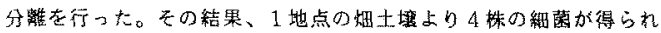
た。分踓株の上記培地て 7 日間培後の nitrogenase活性は、既知

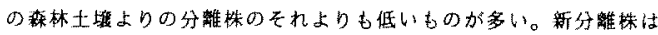
すへてグラム腍性の好気性桿菌で非醉酸性であり、微好気的条件下

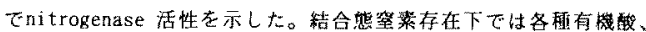

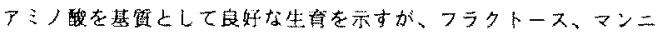
ット、タルコン酸以外の粕類は凟化しない。微好気的条件下では、 せルロースのほか、ヒドロキシエチルセルロースやクルコースをむ

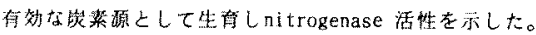

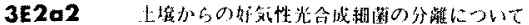

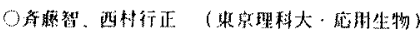

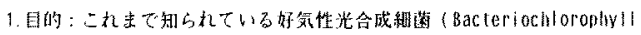

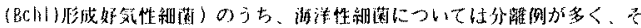

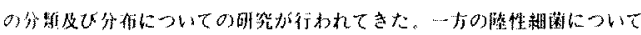

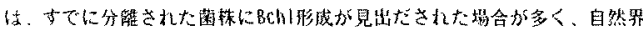

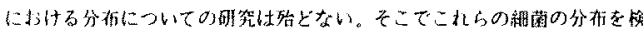

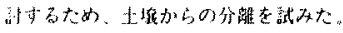

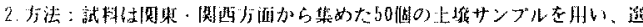

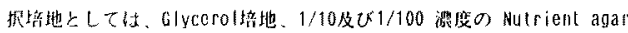

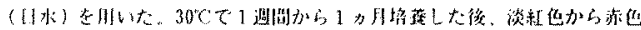

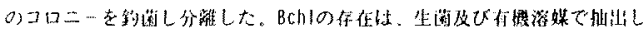

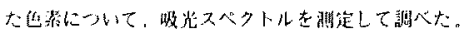

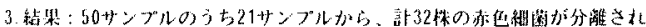

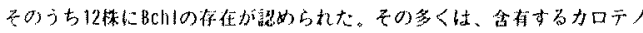
$1 \mathrm{k}$ 世等加pseldomonas radiora (Hel hylobacteriun radiotolerans) k

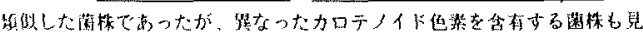

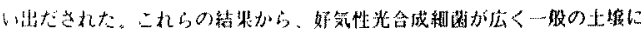

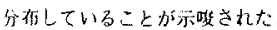

3E2a3

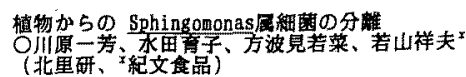

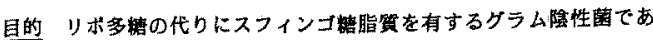

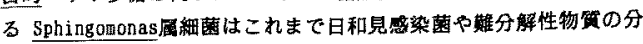
解菌として分蜼されてきた。しかし本来の生息堪所についてはこれま であまり知られていなかった。今回我々は主にイ亦科稙物の糟を材料 として Sphingomonas属細菌の分㒕を武みたのでその結果について報 告する。

方法と結果 1992年の5月から10月にかけて果京近邚の農地およびそ の周迅からムキ、イネを中心としたイネ科植物の糟を探即し、非選択 培地あるいはポリミキシン B含有培地を用いて細菌を分蜼した。出現 したコロニーのうち代表的な形偝を示すものをすへて釣菌し、菌体脂

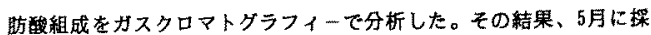
取したムギからは Sphingomonas型の脂肪酸組成をもった菌を全く分

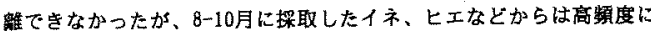
目的の脂助酸組成をもった落を分踓することがでさた。またボりミキ シンB含有培地はこのタイブの菌を分唯するのに有奻であることがわ かった。今後分蜼蔽㧣について分類学的な性状を調へるる予定である。

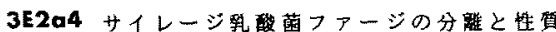

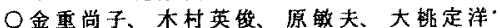

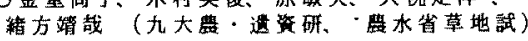

(目的】本研究は、日本の気侯風土に通したサイレ一 污調整用乳酸菌の作出を目漂として、サイレージ酸菌 のベタタ一化用ファージの位路を行うことを目的とした。

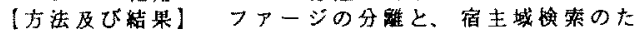
めの指示薄として、サイレ一ジより分睢した高温通応性

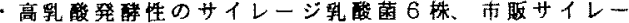
渭酸菌 6 株、Lactobacillus plantarum

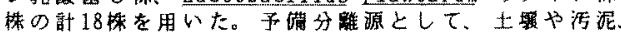
サイレージなどについて謂查を行つたところ、サイレー シ試料のみにフアージの存在が確認された。次いで、サ イレージ26䧕料にっいて同滕に調查行ったところ、半

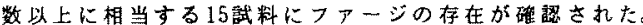

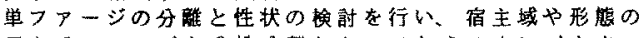
異なるファージを6株分離した。これらの中にべター 化に有用な沿原姓を示すものを櫂好た。

本研究により。サイレージ中に多数のフアージが存在 し、ファージ活染が进んでいることが分かつた。また。 分離したどのフアージにも非感受性の菌橉が遥则できた。

3E2a5

$$
\begin{aligned}
& \text { レンダッウ根粒菻より分陮した Enterobacter cloaca } \\
& \text { によるレンダソウの根䊀形成に与える影矰 }
\end{aligned}
$$

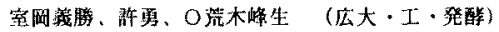

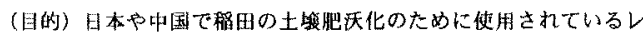

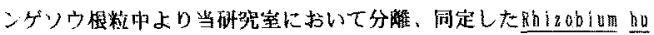

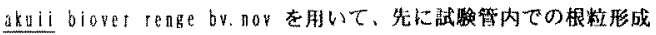

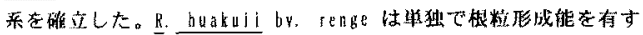
ろが、ここではレンゲソウの根稙表面から分触した Enlerobacler

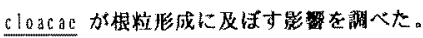

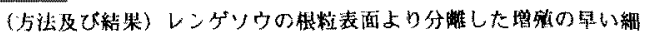

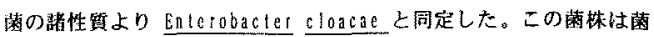

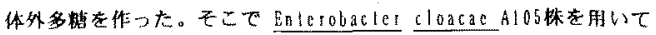

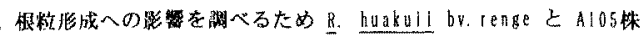

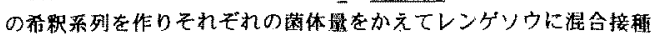

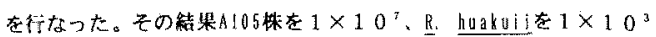

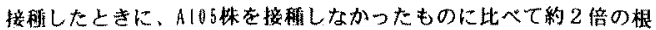
䊉数の增加がみられた。 


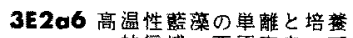
○林信博、西原宾史、石并正治、

Yuwadee Peerapornpisal', 五十秝泰夫

览玉微(東大農化、・チェンマイ大理)

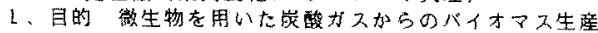

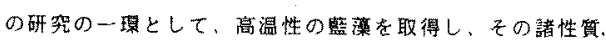

培券条件等について控討した。

2、万法及び結果倸豆などの温点地より採取した試料を 用いて、50ㄷ上で良好に生菿する藍藻をスクリーニン グした。その結果 7 株を取得することに成功し、形墛、運 動性、分裂柾式等加 ると同定された。至道温度はいずれも50”Cで、至適 $\mathrm{pH}$ 6.5〜9.0であった。この中で最も生筒が良いstrain TS-

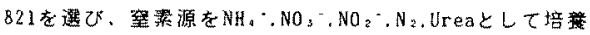
したところ、全ての場合て生育し、等素固定能を持つこと

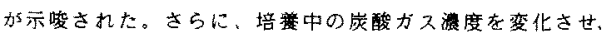

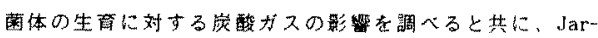

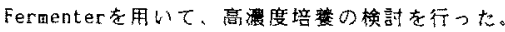

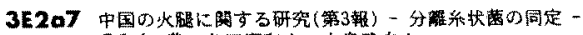

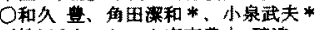

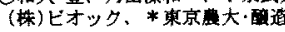

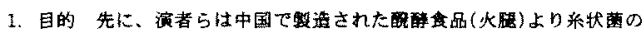

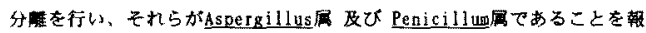

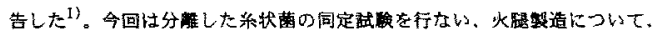
梌时を行ったので報告する。

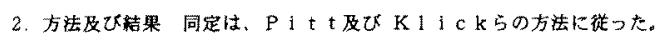

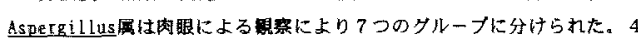
ダルーブが biseriate、3ダルーブが uniseriateであった。各々のグル

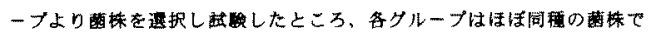

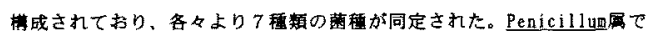
は全菌株をベニシリのタイプよよろつに分け、を机らループより。

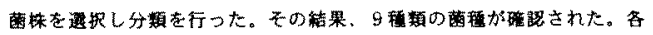

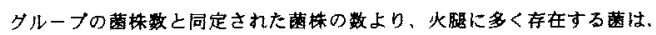
P.aurantiogriseum, P.solitium. P.veridicatium. A.ochraceus, A.

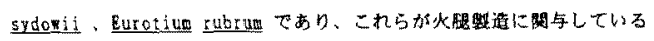
と推定した。

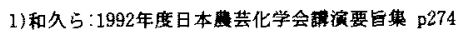

3E2a8 Candida galacta comb. nov., Candida apis var. galactaの程合せ

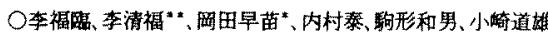

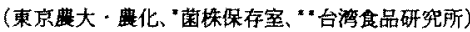

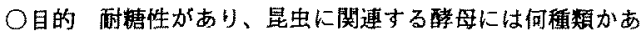
り、それらの表現形䁈は類似している。その中のCandida apis var.galactaは分類位置かいまだ不明である。そこで形

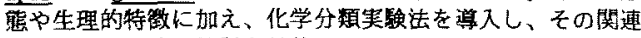

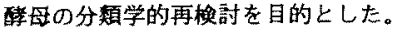

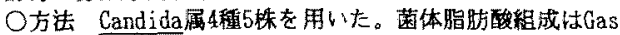
Chromatography、ユビキノン・DNAの塩基組成はHPLCで分析し た。DNA 絸同性はphotobiotin標識miroplate法で算出した。 ○結果 全供陚楼は類似の脂肪酸組成を持ち、ユビキノンと

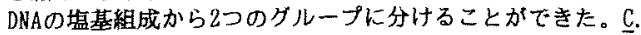
apis var.galacta力 ${ }^{\circ} Q-8 \cdot 50.2$ mol\%、その他 (C.apis、 .

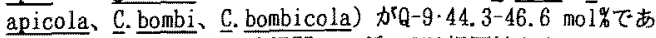
つた。また、これらの醉間での低いDNA相同性からこれらは 别菌種であると判断した。従ってC. apis var.galactaは新菌 種と判断し、新組合せCandida galacta comb. nov.とするこ と老提案する。

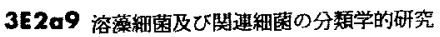

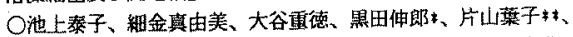

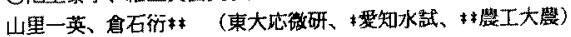

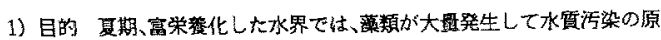

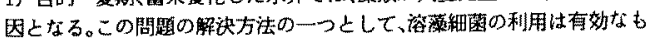
のと考えられ、その細菌群の分類学的㛣討を行う事を目的とした。

2）方法及び結果 諏訪湖の湖心の藏瓷より多数の細菌を分離し、溶澡性

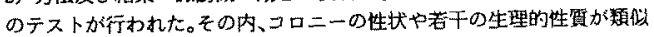

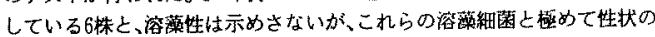
路ている3株の計9株について大谷ら”によって分類学的検徍が行われた 結果、すへての分踓株は、グラム陵性、好気性桿䒩で、ユビキノンはQ-10で

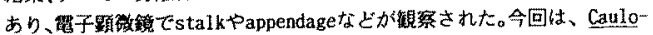

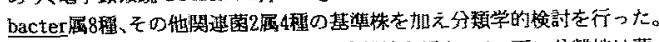
基集株も寸ベてQ-10を有し、GC含置も分離株已近加た。更に分離株络菌

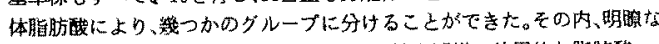

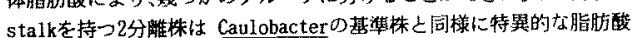

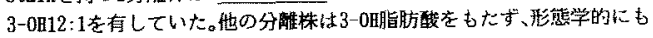
Caulobacter以外の程の基準株に似ていた。更に、DNA-DNA hybridization や筫化性の面から㗢を特定しょうとしている。

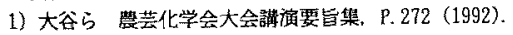

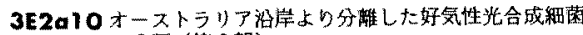 の分類 (第 3 報) ○室賀安隆、西村行正 (東京理科大 底用生物) 芝怛男 (東大 海洋研)}

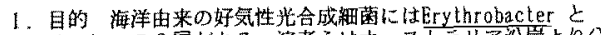
Roseobacter $の 2$ 征がある。演者らは才一ス下ラリア沼厈より分

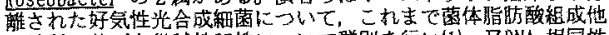

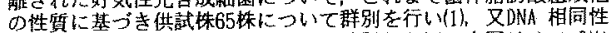
からこれらの群脶の妥当性について検討 $L た(2) 。 今$ 今は hot DNA 增中し更に换討加施た。

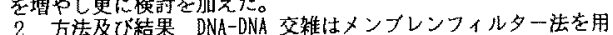

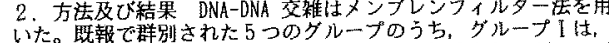

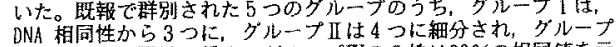

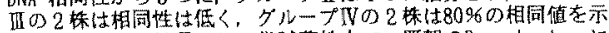

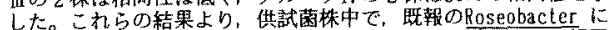

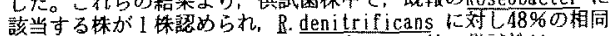
值を示したか，脱空能は認められなかった。他の供試株は， Erythrobacter 及URoseobacter とはONA の相同值は低かった。

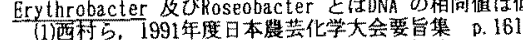

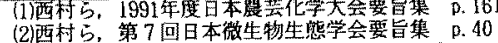

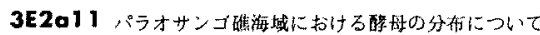

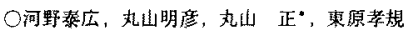
(工技院・微工研，“碀湤洋バイオ研)

〔目的」海洋醉盘の研究は陸上のそれに比心，まだ未知の分野であり，特に

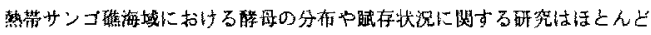

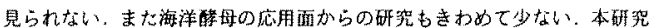

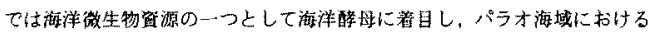
醇母の分布状况を調查するよともにをれらの分離を試みた。

[万法]海水中の醉母の生菌数は，200，25，2000三段階の試料海水老孔佳0.

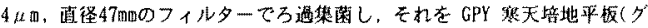

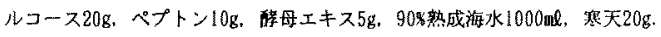
p されたコロニー数摽数(二枚法)して求めた

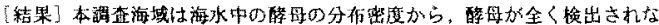

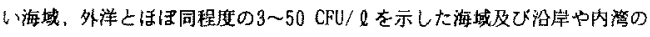

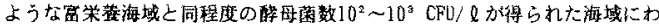

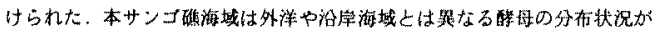
みられた

本研究は大型工業技術研究開発の一瓄上して，新土ネルギー・産業技術

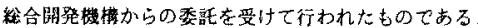


3E2ם12 ニュージーラント産植物より分離した时出胞子形成酵母の分稹 学的研究-Sporobolomyces 属-

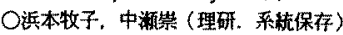

1. 目的 ニュージーランド座植物より分触した射出胞子形成醇母のう

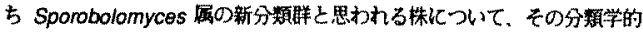
位置を明がしするととを践みた。

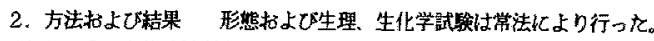

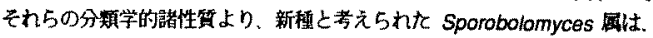

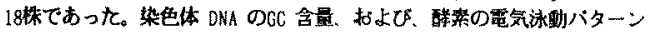
の結果を基にして染色体 DNA の相同性をメンフランフィルター法により

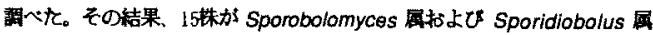

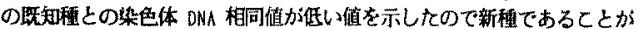

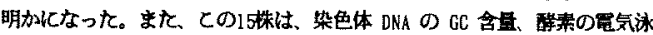
動バターン、抽び DNA 相同值に基ついて5つのダルーブ区别され、各 タルーフは棰に相当すると考元られた。

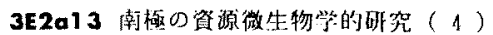 \\ 研因の多様性

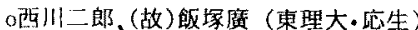

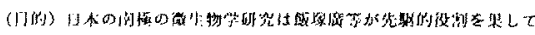

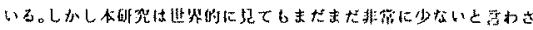

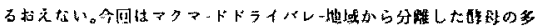

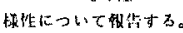

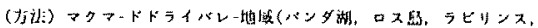

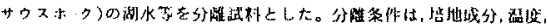

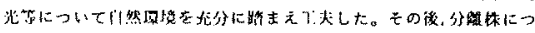

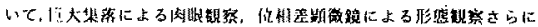

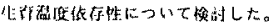

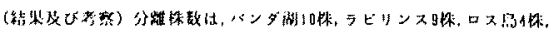

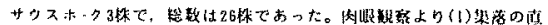

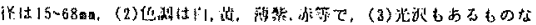

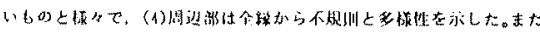

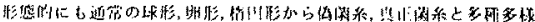

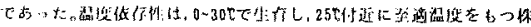

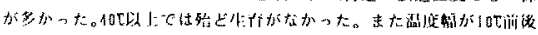

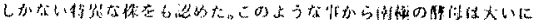

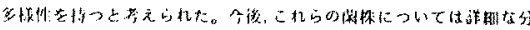

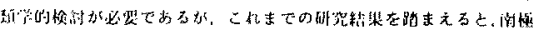

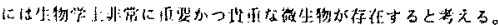

3E2a14 海洋性光合成䎩菌の分堆とその分類学的性鼻

OWanna Choorit、阿部直栰、金子摔、伊崎和夫 （霓北大·店生化）

【目的】海洋性光合成細菌を松島およびタイ国ソンクラ近边

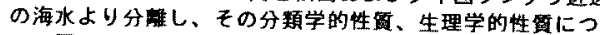
いて調へ、またこれら海洋性光合成湅菌の利用についても 㖟討する事を目的とした。

【方法及じ結果】人工海水を加えた Ormerod 培地を罯択培

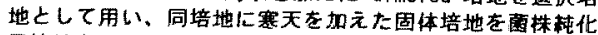

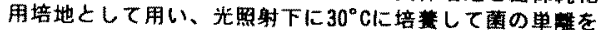
行った結果、了種の海洋性光合成亚菌が分睡された。これら の光合成菌は、いずれもグラム隐性、跡遭動性の ovoid または rod 状であり、Bacteriochlorophylla を有してい た。そのうちの2株はココチン戝，ビオチンお小びチアミン を要求したが、残りの1株はニコチン酸とチアミンのみを要

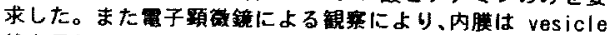
状を示した。2侏のリン脂雷成分には phosphatidylchol ine が存在したが、1株には存在していなかった。またろ株とも ユビキノン10が存在した。

以上より、他の分類学的考実も加えて3视とも Rhodobacter 属であると推定した。
3E2al 5

マツノザイセンチュウの生青阻害性致生物の同定上

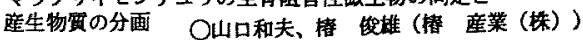

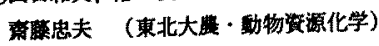

1 目的 松枯九現象は、マッノマダラカミキリにより云播されるマ ツノザインチュウの媩内繁殖により発症する。近年、河律らにより 放腺菌や不完全菌より数センチュウ活性を示す物震が単離された。最

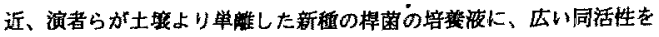

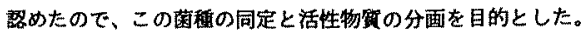

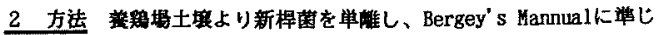

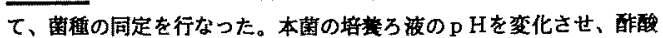
エチ儿抽出法により、水演性区、中性区、酸性区および㙁基性区に分

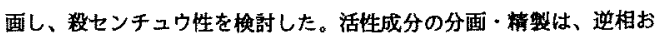
よびイオン交換HPしCにより行なった。

3 結果 単離桿菌は、各種㭲定試䰩によりBacillus sphericus と 同定され、BS-T1と命名した。BS-T1の培爰ろ夜に㤝、マッノサイセン

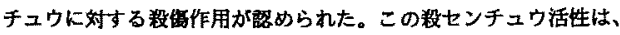

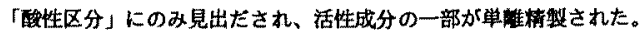
1）山口和夫、偆 捘雄、特䇢 略61-205202

\section{E2p2 深海サンプルからの好圧性微生物の分離} ○加菤千明、皇修一、掘越弘媇（海洋科技七、深海 微生物)

目的：高水圧下の世界である深海に生息する微生物は、そ の環境に適応して特異な性質を示すものと考えられる。そう した深海微生物の中には、常压下よりもむしろ高水圧下を好 んで生育するものがいる。ここではそうした好俚性微生物を 深海サンプルより分噰したので、報告する。

方法と䊅果 : 潜水調査船”しんかい6 500 ”により、駿 河㴒 (深度 $2485 \mathrm{~m}$ )、琉球海满 $(5110 \mathrm{~m}$ )、及び日 本海满（陸側6356 m、海側6269 m) にて深海生物や 海底の泥を採取した。各サンプルは、採取後直ちにマリンブ ロスに照濁し、圧力器器に入れ $65 \mathrm{MPa} 、 4{ }^{\circ} \mathrm{C}$ にて集稹培

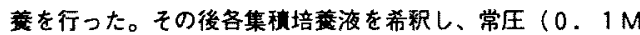
P a ) と加圧下とで培盖を行い加圧下での生育が良好なもの を好圧性微生物として监踓した。その結果、数株の好任性を 示す微生物が得られ、なかんずく日本海溝のサンプルからは、 绝対好圧性細菌と思われる微生物が単隺された。

3E2p3 深海サンプルから分離された好圧性微生物の性質 ○皇修一、加藤干明、掘越弘媇（海洋科技也、深海 微生物)

目的：深海摆境に適応して生息していると思われる好圧性 徽生物をいくつか分離したが、そうした微生物がとのように 深海という高水在下の世界に暗応しているが非常に興味深い。 ここでは深海サンブルからら得られた好压性微生物の特徽をい くつか調べたので報告する。

方法と結果：本研究空にて分離された好性性微生物につい て、M2216培地を用い温度と圧力の関係について検討を 行った。その結果、一部の好圧性微生物において10 Cの培 变において者しく好圧性を示すものが、4 好性性が失われるといった性質が示された。また、10 生育した好圧性微生物の各圧力下における培䔄時の細胞の形

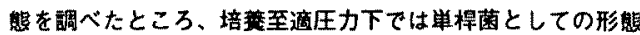
を示したが、より常任に近い圧カ下では細胞が長くなる特徽 が見られた。現在低栄美培地を用いて各微生物の生育に対す る圧カの影䈏も検即している。 
3E2p4

深海由来の有機溶媒酎性菌の諸性質

森屋和仁、掘越弘媇 (海洋科技也、深海微生物)

（目的）演者らは、樑海底泥を分離源とした場合、陸上土 境と較へて高い頻度で有機溶媒柇性菌が分蜼されることを報 告した ${ }^{1)}$ 。その後、さらに高濃度有機溶媒存在下で增殖する 細菌の分離を目的として㥞々な深海試料より検索を行なった。

（方法）深海底泥を50\%有機溶媒で処理し、有機相を直接

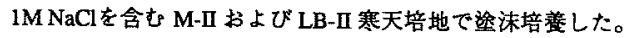

（結果）相模淯の深度 $1100 \mathrm{~m}$ の底泥より20\%ベンゼンおよ び50\%トルエン存在下で增殖する、クラム陽性胞子形成桿菌 (DS-962) およびクララム陰性桿菌 (DS-1051)を単離した。これ らの細菌は、耐盐性を示し、炭化水素を分解した。また、べ ンゼン、トルエン、およびキシレン等の有機溶媒に附性を示 したが、和性と $\log P$ 值との明確な関連は認められなかった。

1) 国祭マリンバイオテクノロジー学会要旨 p.86(1991)

\section{E2ps 有機溶媒酎性炭化水菜分解細菌の生理的性質} ○高木善弘 策和仁 排越弘新 (海洋科技七 深海微生物)

今回報告する有機溶媒耐性炭化水素分解細菌は、”し んかい2000"により探泥した䮑河湾の底泥から森屋らの方法” により単雉した。この单㩁した細菌DS-711株は、フラボバクテ リウム属に属し、石油中の主成分である直鎖の岸化水菜類を分 解し、さらに種々の有機洛媒、特にベンゼンに対して耐性を持 ち、高浱度の食塩存在下でも生育した。本菌は，炭化水素を利 用する柡，界面活性郕栚の物啠 (ES-compond)を生産し油滴を 乳化、可溶化した。このES-compondは糖と蛋白質の複合体であ ク、その活性にはカルシウムイオンを必要とした。至適 $\mathrm{pH}$ 7 付近であり、禹源度の塩存在下でも活性を示した。

本菌をkeroseneを添加し培菱した祭、可逆的な細胞形態の変化 が観察され、この形態变化に付随して本菌はより高い炭化水素 分解能、有機溶媒耐性を持つことがわかっだ。以上の結果より、 本菌は海水中において高以原油分解能を持ち、その細胞形態を 変化させ適応していると考えられる。

1) 国際マリンバイオテクノロシー要旨、D $86 、\left(\begin{array}{lll}1991\end{array}\right)$

\section{E2p6 深海底より分暲した有機溶媒稆性イオウ酸化細菌 の硣性留 \\ 服卷辰則、森屋和任、掘越弘媇 \\ (海洋科技七、哚海微生物)}

（目的）演者ら注、石油製品の脱硫を目的とした、水一有機

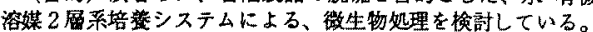
そのために、有機溶媒政性かつイオウ酸化性を示寸微生物の 検索を行なった。

（方法）有機浴媒酎性イオウ酸化細藏の険索は、森屋らの 方法りにより行なった。得られた蔽侏は、有機イオウ化合物 を含むモアル石油の微生物処理に供した。モア゙ル石油として は、1\%ベンせン添加のケロシンおょびジーゼル油を用いた。 有機イオウ化合物として、チオフェン(TP)、ジベンゾォオフ エン(DBT)まだ、エチルメチルスルフィト(EMS)を全イオ ウ分 $0.2 \%$ となるように添加した。生成した硫酸イオンの検出 は、イオンクロマトにより行ない、全イオウの定異はCHOS 分析装道用いて行なった。

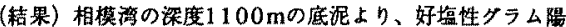

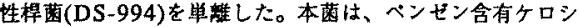
ンの存在下で、千才硫酸イオンを酸化し、かっペンゼン含有 シーゼル油中に淑加したTP、DBT、およUEMSを分解し硫酸 イオンを生成した。

1) 国碗マリンハイオテクノロシー学会要旨 p.86(1991)
3E2p7

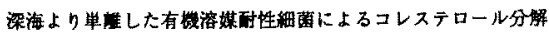

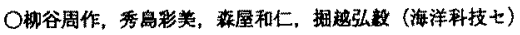

く目的〉ステロイド数は高庭に水に不溶性であるが放，現在結晶發醉法

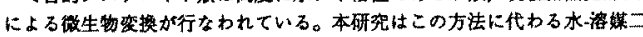

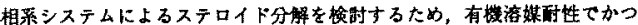

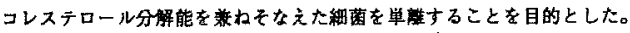

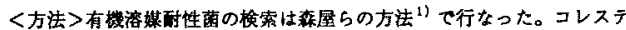

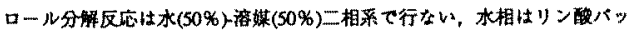

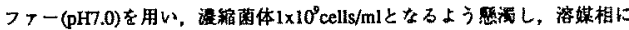

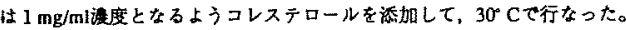
コレステロールの定買はLiebermann-Burchard比色で行なった。

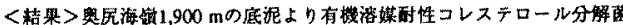

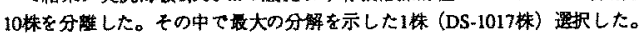
本菌株はクラム隄性桿菌て、、ヘンゼン、トルエン、及びへキサン等に溶解

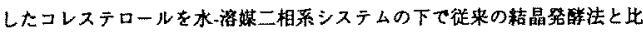

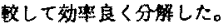

(1)国祭マリンパイオテクノロジー学会要旨, p.86、 (1991)

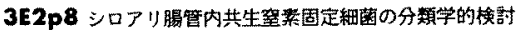

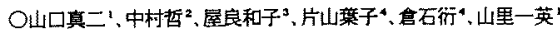

('果大心微研、“琉球大理、“琉球大教荟、“東京農工大蕽)

[目的］先に、渎球列島産シロアリにおける空素固定能の存在苝ひに、

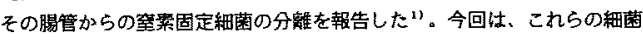
の分類学的㕸置について模卻を行なった。

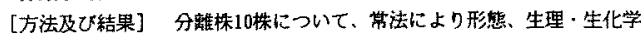

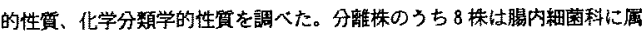

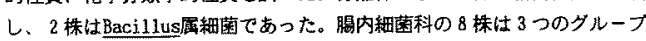

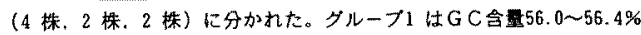
で、呼吸系キノンは0-8、MK-8、DMK-8、グルーブ2は55.1〜57.2\%で、Q-8、 グルーブろは54.8〜55.7\%て、、-8、MK-8.DMK-8であった。 Bacillus属細菌

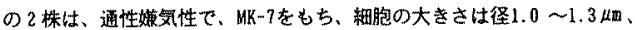

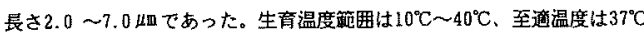
で、ア三ノ酸の要求性を示した。分離株の1株（PN-2）には，胞子の

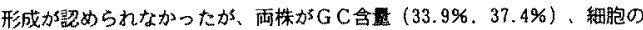
大きさ、生理·生北学的性䓄に放いて、Bacillus cereus と海完全に一 致することから、本㮴に屈すると同定した。

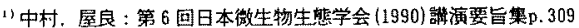

3E2p9 シロアリ生態系からの塩化ビフェニル分解菌の単離 と解析

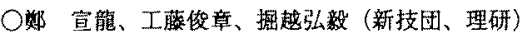

【目的】ポリ塩化ビフェニル (PC B ) は、その強い残留毒 性のために重大な環境污染物缰であり、このような P C B を分 解する細菌がいくつか単襍され、群細に解析されている。 PC Bの基本骨格はビフェニル（B P ）であり、B P梳りグンン成 分の約 $20 \%$ を示していることから、PCB分解遺伝子はB P 分解透伝子から進化して来た遺伝子であろうと思われる。以上 の観点から、我々は植物の湅胞壁を分解できる能力を持ってい るシロアリの生態系から、塩化B P分解菌の単離を試みた。

【方法及び結果】シロアリを隇菌水で3回洗い、清した抽出 液を B P 添加C培地 $\left(\left(\mathrm{NH}_{4}\right)_{2} \mathrm{SO}_{4} ; 5 \mathrm{~g}, \mathrm{~K}_{2} \mathrm{HPO}_{4} ; 2 \mathrm{~g}, \mathrm{KH}_{2} \mathrm{PO}_{4} ; 1 \mathrm{~g}\right.$, $\mathrm{MgSO}_{4} \cdot 7 \mathrm{H}_{2} \mathrm{O} ; 0.2 \mathrm{~g}, \mathrm{CaCl}_{2} ; 10 \mathrm{mg}, \mathrm{FeSO}_{4} \cdot 7 \mathrm{H}_{2} \mathrm{O} ; 10 \mathrm{mg}$, trace element

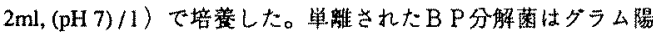
性の短楻菌であり、基質である2,3-dihydroxybiphenylを分解して 黄色くなることから、本菌は2,3-dioxybiphenyldioxygenaseによる $m$ 一開裂释路を有していると推定される。現在は更に詳しい解 析を行っている。 
3E2p10 塩化ビフェニル分解菌 Bacillus circulans の单都と解折

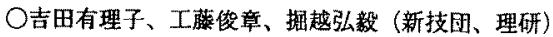

【目的】ポり塩化ビフェニルは世界的に分布している難分解

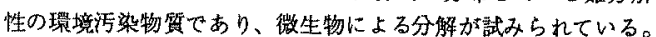
今までに分離、険討されている菌の多くは、Pseudomonas属を はじめとするグラム陰性菌である。今回、我々は、進化の面か

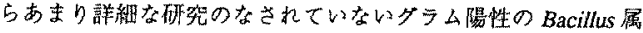
細菌を単離し検討した。

【方法及び結果】埼玉県内の土壤をビ】ェニル添加培地で集

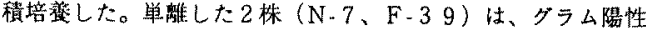
程菌で、胞子を有し、その他の諸性質から、Bacillus circulans 推定された。これらの菌は、塩化ビフェニル添加培地でも生育 した。中問代謝物である 2,3-dihydroxybiphenyl を每えると、頡 色登色することから、メ夕開裂の代謝経路を持つと推定される。 琴在更に詳しい解析を行っている。

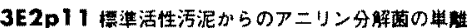

(住友化学工燥 生物环境科学研究所)

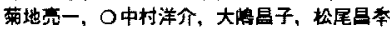

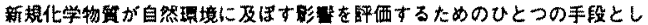

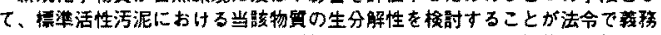

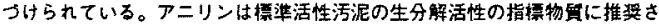
れているが、橙準活性污泥中のアニリン分解菌のキャラクタリゼーションや

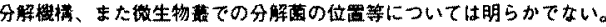

演者らは、アニリン $100 \mathrm{ppm}(0.01 \%)$ 及ひ1000 ppm (0.1\%) 脽一

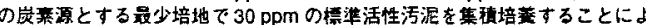

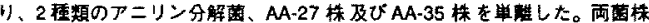

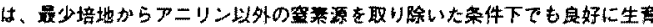

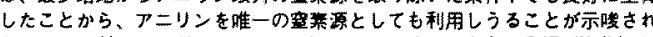
た。AA-27 株はアニリン $2000 \mathrm{ppm}$ 以下でアニリンを完全に分解（資化） たが、AA-35 柇低度アニリン苗菌時（300 ppm 以下）においてアニり 異化代激に由来すると思われる黄色の物貿を座生する傾问加银察された。

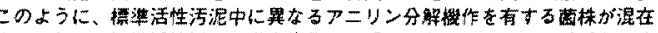

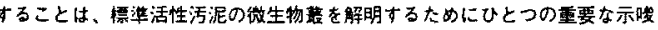
を与えると考えられる。

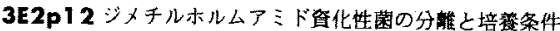

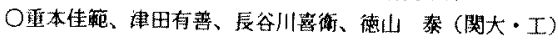

昷的 アミン柔有樴化合物は、溶媒・容制として工紧的に広く用い られている。しかしながら、アミン系有機化合物を教果的に処理し 得䓃微生物は、あまり知られていない。本研究では、代表的なア ン系化合物であるジメチルホルムアミド(DMFA)を分解する数生物の

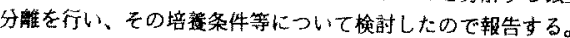

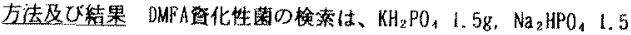
g. $\mathrm{MgSO}_{4} \cdot 7 \mathrm{H}_{2} \mathrm{O} 0.2 \mathrm{~g}, \mathrm{CaCl}_{2} \cdot 2 \mathrm{H}_{2} \mathrm{O}$ lOmg. $\mathrm{FeSO}_{4} \cdot 7 \mathrm{H}_{2} \mathrm{O} 5 \mathrm{mg}, \mathrm{MnSO}_{4} \cdot 4$

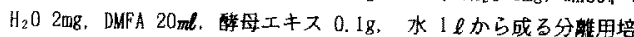

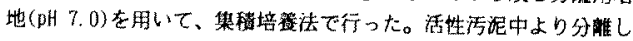

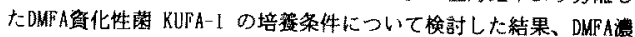

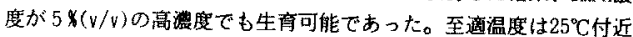

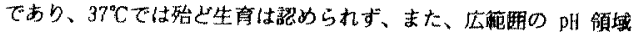
(pH 6-10) で生南可能でおった。本荣株は、OMPA以外にもォチルア ミン類 (ト・・・竞)等のアミン系化合物に生育可能であった。見在、

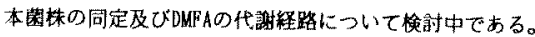

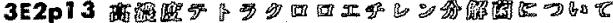

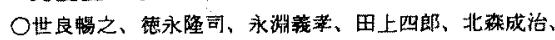

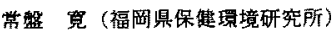

テトラタロロエチレン(PCE)等の㗑発性有機塩表化合物によ る地下水污染は世界中て重大な事熊を招いており、菠本的な观 理方法を早急に開発する必要に迫られている。我ヶは、微生物

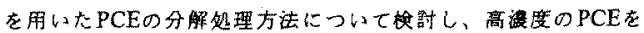
奻率良く分解する䟤菌を単睢したのてその特性について報告す る。PCE分解菌は矢口 5 のMMY培地を用い、過去にPCEに污架

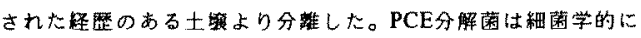
見て生化学性浆の異なる通性缣気性 3株で、そのうちの2株 (K-26、K-35)はPCEをトリクロロエチレンに、1株(Y-51)はPCE を cis-1,2-ジクロロエチレンまで分解する能力を訮光ている。

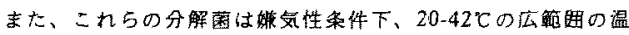
度城て最高160mg/1のPCEを3-7日て分解できる。高遮度のPCE

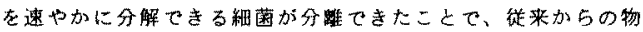
理化学的处理方法に加光、新たに微生物に上るPCE净化が可能 でると思われる。

3E2p14 Acidiphiliua aminolytica sp. nov.: 広いアミノ化资化

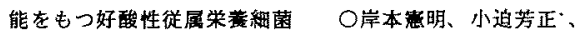

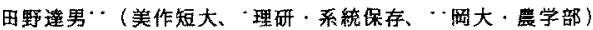

1.目的中温好酸性従属栄蓞細菌であるAcidiphilium属は現在 5

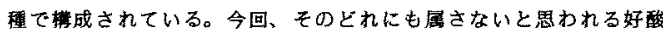

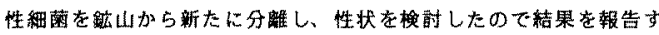
る。 2. 方法书上び結果 Acidiphiliun 属 5 種、Acidomonas

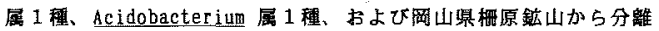

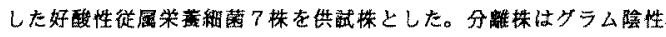
好気性㭷菌で、ウレアーゼおよひ馬尿酸分解活性が陽性であった。 分雜楼は糖類以外に lysine, arginine, glutanate, $\beta$-alanine, 5-aminovalerate, diaminobutaneなど既知䧳に比バて多程類のアミ ク酸およびアミンを資化した。 $\mathrm{G}+\mathrm{C}$ 含量は 58.7 59.1 mol\%、主要 なイソプレイトキノンは Q日、脂肪酸は $C_{10: 1}$ で、らに 2-0H

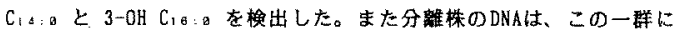
虽する分路株のDNAと慓い相同性（76〜100\%）を示したのに対し、 既知種のDNAとは低い相京性 (2〜29\%) しか示さなかった。以上の 結果か5、分踓株は Acidiphiliug 属の新程と判断し Acidiphilium aninolytica sp. nov.を提唱する。

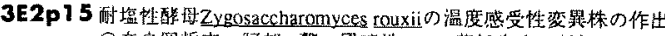

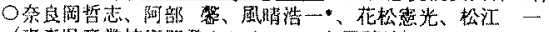

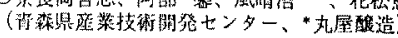

（目的）味暂は熟成終了後にアルコール添扔や扣熱処理が施されている。

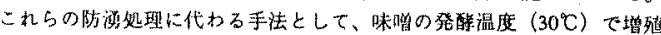

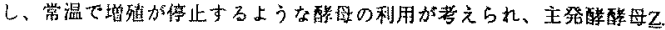

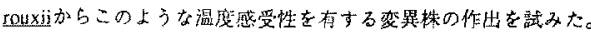

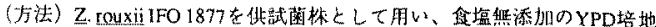

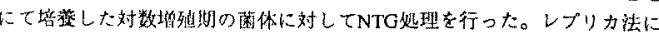

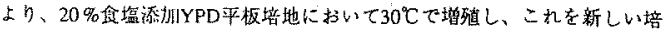

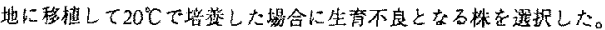

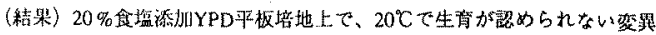

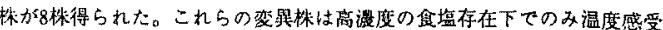

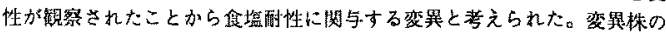

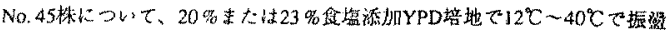

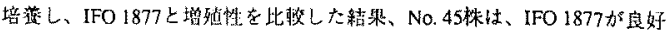
に增愐する260付近を境として、それ以下の温度では影著に增列速度の低

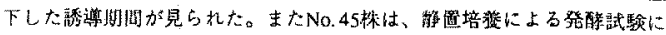

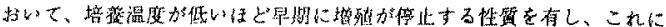

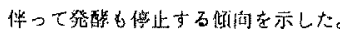




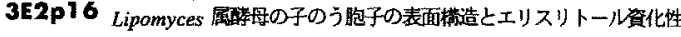

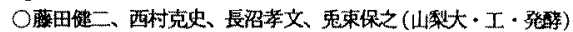

目的：我々の研究空で佶、ここ数年来土烄からLipomyces およびを の関連属に属すると考えられる醇母約110菌株を分解して、主とし

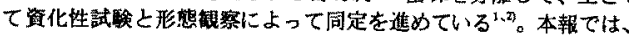
Lipomyces 属瞵舟の種レベルでの重要な分類指標となっているエり スリトール資化性と子のう胞子の表面楼造の関連性について報告 する。

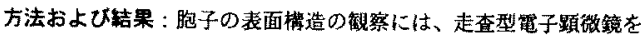

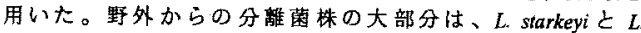
kononenkoae 之を区別するエリスリトール資化性試縗の結果か子の

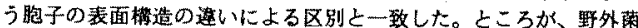
株のいくつか、および公的機関から分㳟された菌株の中には、盷

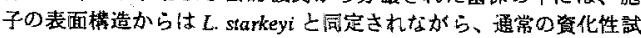
験ではエリスリトール資化性が裔ガティプという L kononenkoae としての性䁈を示すもの加存在した。吖上の結果から、L starkeyi であるか L kononenkoaeであるかを判定する基慗としては、一般 的に用いられている上述の方法は遒当ではないと考えられる。また 両種が区別できる有効な方法についても检討した。

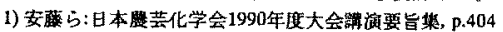

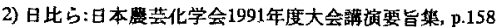

3E2p17 抵抗性カードラン定加水纷解し、ラミ゙リリビオース老生浲する Bacillus circulans complex 0 图们ついて

○神㴖复美、金長和子、原田第也、原田 明“，横田 明”*

(神戸女子大、"阪大理、" 発醉研、大阪)

【目的】カードンンを水中て $120^{\circ} \mathrm{C}$ 以上で加熱すると醉素や酸に対し て琵抗する部分ができ、これを抵抗牲カードンとよんだ。私達はこれ

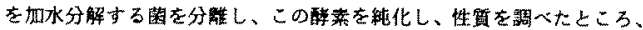

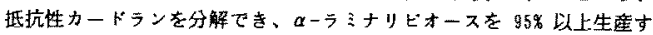
る醅菜でることを明らか代した。この報告では抵抗性カードランを分

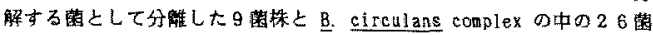

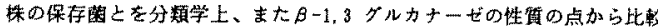
Lt。

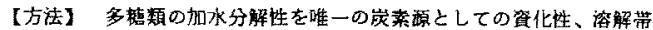
の有無で謂くた。またカードランな゙で培盖した上澄被中のタンバク質

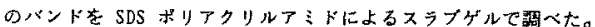

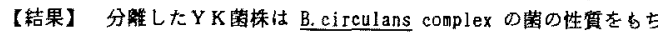

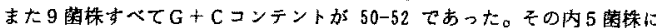

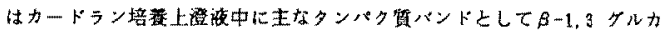
ナーゼがみられ、その粗䣼による生産はラミナリビオースであった。

これらの菌秼はすべてプスッラン、デンプン、ブルランを加水分解した。

3E2p18 Saccharomyces cerevisiae 怆 の暒延性ホモタりズムの解析

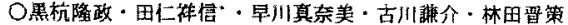

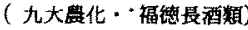

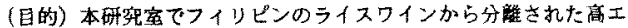

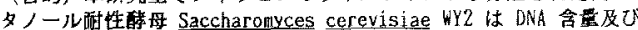
四分子分析の結果から二偣体絧胞であると考察された。しから。同 一四分子中心接合能に関して、Materと Non-mater 加2:2に存在 した。このうち Non-mater 株は正常なホモ夕リズムをしたか、性

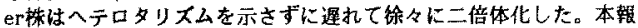

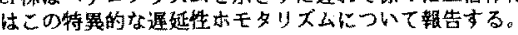

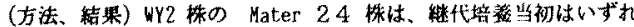
も Mater のままで胞子形成能を示さなかったが、20回継代培策後

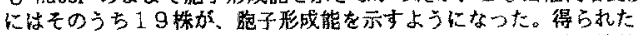
子のうの胞子は全て Mater で、さらにこの Hater 細胞は線代培羡

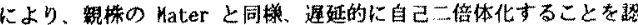

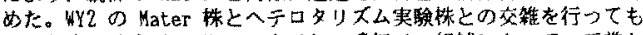
子のう胞子怯すべて Mater を示し、㟟伝子の相補によつて、正常な

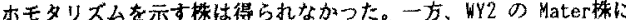

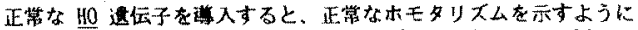

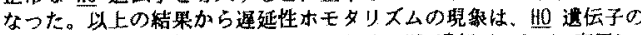

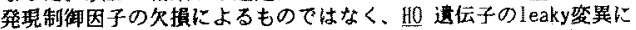
よるものと孝察した。
3E2p19 水瑟酸化能を有するNerononas C 5-1株について 西村行正、関根箱

（東京理科大一広用生物）

1.目的これまで水秦細菌については、Pseudononas他17属に属する 湅菌が知られている。演者らは、水素酸化能の倒れた株の取得を目的

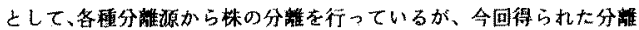
株の中に heromonas 属に属する株を㑇好たので報告する。

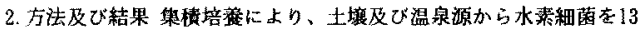

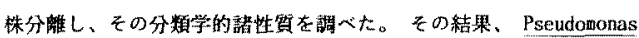
及びAlcal igenes 等に属する株に加元て、今まで埌告されていない

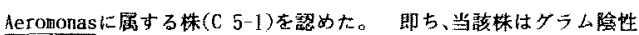

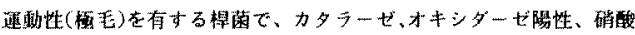
篮索還元し、糖を発醉的に分解、0/129耐性、カゼイン、゙ラチン、デン プン、Tween80等を加水分解し、Na'要求せず、arginine dehydrogenase

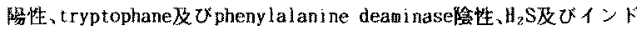

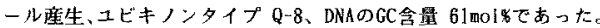

3E2p20 マルトースからの新規エタノール発磷細菌: Zymobacter maltophilusgen. nov., sp. nov. O网本智之，池录裕，石石衍”、 北里一英“(キリンビール基盤研、東京费工大”、東大応微研”）

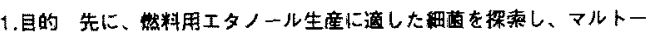
スより培地中 $8 \sim 10 \%$ のエタノールを生産する細菌 4 梌を、Palm sapd り分離、報等しだ。本報ではこんらの分数学的位置について報告する。 2.方法およひ結果 常法汇より、形態、生理的性劕、化学分類学的性留

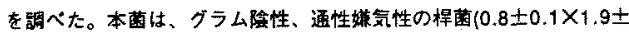
0.6)で周毛を有する。カタラーゼ、MR、VPは陽性。オキシダーゼ、イ

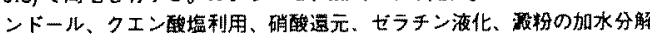
は除性であった。生育にニコチン酸を要求する。生育钴囲は、温度21

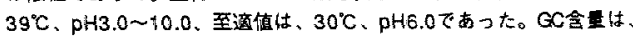
$55.8 \pm 0.4 \mathrm{~mol} \%$ 、呼吸系キノンは、Q-9であった。主要菌体脂肪酸は、

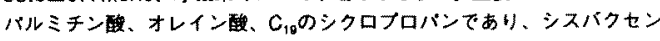

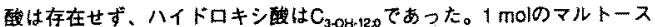
より 4 molのエタノールを生産した。これらの分類学的性貿より、分離株 は、既存エタノール発醉䋖菌 Zymomonas (Kluyner and Niel 1936)。 Saccharobacter(Yaping et al. 1990)とは別属と考元ら九、新属、新種 Zymobactermaltophilus を提唱する。

1) 周本5:1991年度日本费芸化学会大会謤演要旨集 p177

3E2p21生酛中の乳酸兽について

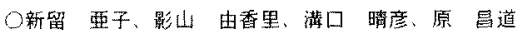

$$
\begin{aligned}
& \text { (蔽正宗酒造・総研) }
\end{aligned}
$$

【目的】生配柔酒母中の乳酸菌群の菌蕧については古く片桐らの 研究によ り Leuconostoc mesenteroides var sake とlactobacillus

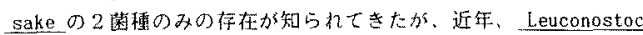

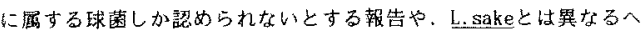

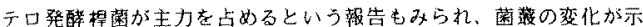

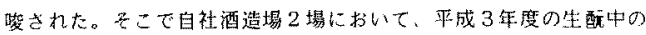
恎酸菌群を見直した。

〔万法拉よび結果】乳酸菌同定マニュアルに従って分類を行い、 Bergey's Manual of Systematic Bacteriology(1986)の記械加5。 分雄された球菌11株は全て Leuc. mesenteroides subsp. mesenteroidesと同定さ机た。さらに、诨橉については Digoxigeninラベル (BM)した全DNAをプローブを用いてトットプロットにより DNAーBNA ハイブリタイゼーションを行い、分離株15株全てが L. sake と同定 された。これらの2稿の菌が主力を占めた要因についても改めて梌 討を試为る。 


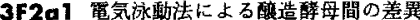

○山本京子、門會利守、中里摩实、竹田正久、金子太吉

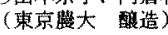

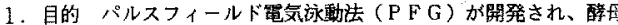
の染绝体D NAの分離が可能となった。酸造塐母のうらワイン睹母の

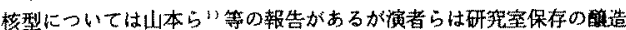
醉母（S. cerevisiae）の核型についてPF G 法で检討した。また、碚 母細胞肉蛋白質のアクリルアミドゲル電気泳動法による比較も行った

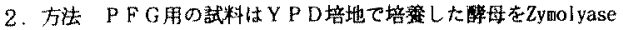
100Tを含むローメルトアガロース包埋でプロトブラスト化した後、プ ロテイナーゼKで処理した。このサンプルプックをクロモソーマル グレードまたはP F C アガロース（BIO-RAD製）で嘀製したゲル、100 秒〜45秒のランピンタパルスなどの策件空用いて、CHEF-DR RAD製) て被動した。アクリルアミドゲルによる酵母細胞内蛋白質の 永動にはアトー社の装筧を使用した。

3、結果 PFGの結果はサイズの大きい架色体について明硫な留同

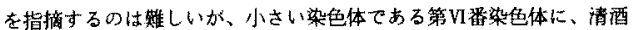
醉母と他の実用䤃母間には一定の差が見られた。アクリルアミドゲル に上る蛋白の永䣦では 3.7万ダルトン付近に、清酩醉特に有のバ ターンが瑟的らた。

1)N. Yamanoto et al. Am. J. Enol. Vitic. 42.358(1991)

3F2a2

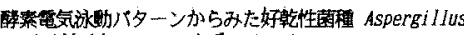
penicilloides のアイデンティティー

O田村美貫、Connie Fe C. Gibas*，杉山純多

(果大底㳊研、*フィリビン大学)

1. 目的：好乾性萗程 A.penicilloides に属する菌株について、そのア

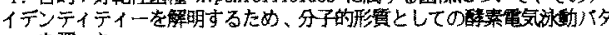

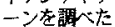

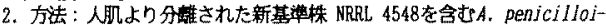

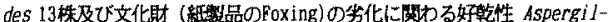

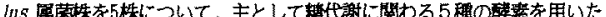
ボリアクリルアミトスラブゲル電気泳娌法によりそのパターンを謂へ、相 対移野度 $(R \mathrm{~m})$ 值に基ついた数值分頑を行い、その桔果をテントログう

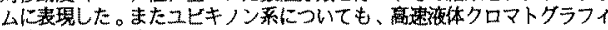
一法を用いて同定した。

3.結果: A. penicilloides 13敉は,Aspergillus spp. 3株 $\left(Q-10\left(\mathrm{H}_{2}\right)\right.$ を除き、すべてー9であった。デドログラムたおいて、A, penicilloi

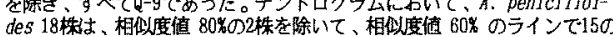

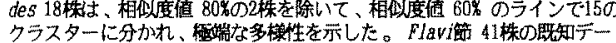

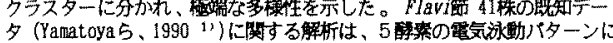
おいて相似度值 60\%あるいはそれ以上の值を元す本菌株は同程である、と

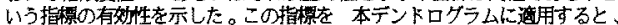

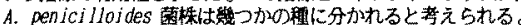

1) K. Yamatoya et al., Modern Concepts in Penicillium and

1) K. Yamatoya et al., Modern Concepts in Penicillium and
Aspergillus Classification, Plenum Press, New York, 395-405(1990)

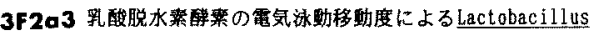
acidophilus groupの同定

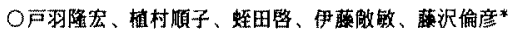
（東北大·搌·生物生産、“神奈么衛研）

1 目的 L.acidophilus groupはt卜消化管内Lactobacillus中の最

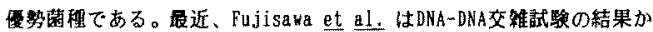
5L.acidophilus groupかsL.acidophilus 、L.crispatus, L.amylovoru S、L.gallinarum、L.gasseri、L.johnsoni1の6 菌程に細分されること

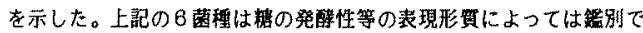

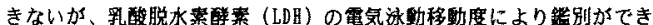
るのではないかと考えて、その可能性を橹討した。併せて、ヒ卜乳幼

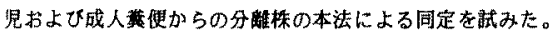
2 方法菌体を超音波破碎して得た無細盷抽出液を、スラフ型机リ アクリルアミトゲル電気泳野により分雄後、活性桇色してD-LDH台よひ し-LDのバンドを㛟出した。

3 結果 D-LDH书よびLーLDHの移動度の比によりL.acidophilus gr

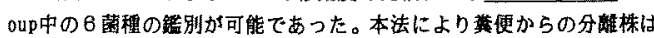
L.acidophilus、L.crispatus、L.gasseriと同定された。

(1)T. Fujisawa et al. Int.J.Syst.Bacteriol., 42，487-491(1992).

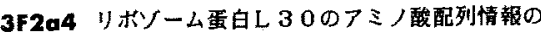
菌分類学への度用

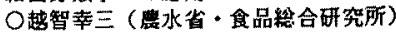

1.目的 ごく最近、我々は放線菌のリボソーム蛋白AT-L300電

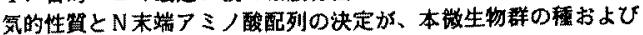
属レベルでの分類学に非常に有效な手法となることを報告してき，

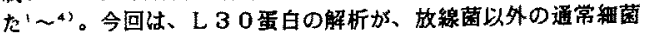
の分類学に広用できるか否か橹尌した。

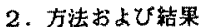

通常細菌の代表として、Escherichia, Bacil lus, Staphy lococcus, Psuedomonas, Leuconos tock, およU'Lactobacil lusを試雅した。 L 30蛋白のアミノ酸列は、50〜150ピコモルの試科を $20 \sim 25$ 残基まで决定した。

放線菌の塄合と兴なり、いずれの細菌む電気的性算はほほ定 (REM70前後)てあった。ところが、アミノ酸配列は各属で 非常に貲なっており、属しベルでの系统阙係の解明に有效である ことが示唆された。Bacillus属の場合、属内においてされ配列に 著しい䔔いがみられ、本属が、ヘテロであると推定された。 (1)Int.J.Syst. Bacterio1.41,234(1991)

(2) Int.J.Syst. Bacteriol.42,144(1992)

(3)Int.J.Syst.Bacteriol.42,151(1992) (4)Gene 115,261(1992)

$3 F 2$ a 5

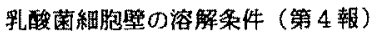

=細胞暨ペブチドグリカン成分の検討 $=$ ○高橎正明 岡田早苗" 内村秦 小崎道雄"** 駒形和男

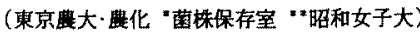

○目的 演者らは乳酸菌から容易にDNAを取得できる条件の確 立を目的としてその細胞壁のlysozyme耐性について换討し、

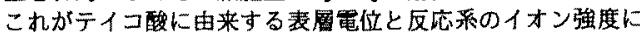
影瑟されることを報告しだ”。今回はIysozyneの作用基望で あるpeptidoglycanに着目し耐性に影響する因子を検索した。 ○方法・結果 十数梅の乳酸菌の細胞壁画分について成分分 析を行った結果、細胞壁のlysozyme酎性と peptidoglycanのア ミノ酸組成およびpeptido鎖による架橋の程度に相関は認めら れなかった。しかし、耐性を示す細胞壁において、一部のグ ラム陽性菌でlysozyme附性の原因とされるエステル結合型ア

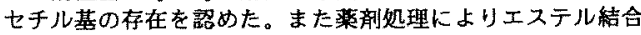
型アセチル基の遊䅸にともなうlysozyme耐性の消失を確詺し たことから、こ犰が乳酸菌においてもlysozyme耐性の一因と なる可能性が推祭された。現在、演者らはこの知見に基づい た溶菌法を碓立しDNAの取得に利用している。

1）日本農芸化学会 平成 3 年度大会要冒集 p. 330 .

3F2a6 Microplate hybridization(MPH)法による 乳酸菌の簡易同定条件の検討

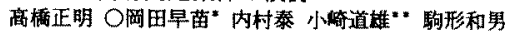

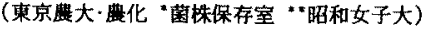

O目的 MPH法はDNA homologyk必要な定量的hybridization 法のひとつである。従来法と違いRIを使用せず使用DNA量も微 量であることから、分類学的㛟討の手法としてのみでなく简 易同定の手段としても注目されている。乳酸菌においても表 現形望による菌種の決定が困嚾で、DNA homologyの㛟討が不 可久になりつつある菌群が多数存在する。このことから、MPH 法を利用した乳酸菌の簡易同定法について梚討を試みた。

○方法 釈酸菌の溶菌は困奞であることから、前演者の知見

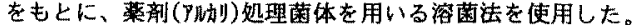
MPH法は江奇らの方法”を参考に営光梚出系を用いて行った。 ○結果 ここで提示した溶菌方法の利用により強固な1ysozyme耐性を持つ"Lactobacillus batatas”を含む乳酸菌群より DNAを取得できた。また、本法で取得した基紫株DNAとミクロ チューブ中で抽出した試娩株DNAのhybridizationによって DNA homologyにもとつく試験株の简易同定が可能であった。 1) 扛踦 ら Int. J. Syst. Bacteriol. 39, 224 (1989) 


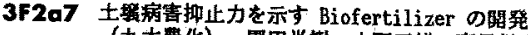

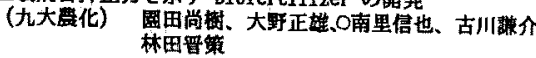

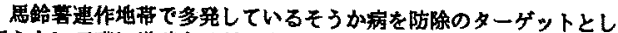

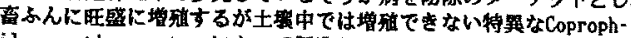
ilous actinonycetes によって㹕造した Biofertilizer を施用して

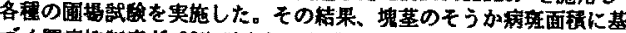

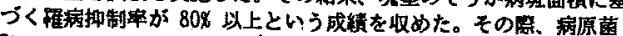

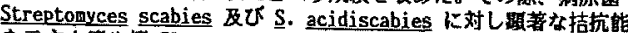

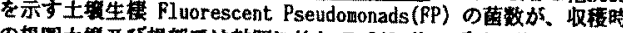

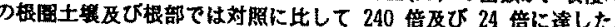
本瓶は.この Biofertilizer の防除能の起因について格斯したも のである。

Biofertilizer 中では、どの pHにおいてもそうか病仙增殖しな

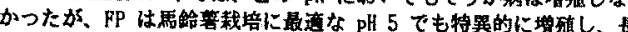
期に洨り $10^{7} \mathrm{CFU} / \mathrm{g}$ という言い药数を保持した。また、車病原蔡に 対して明著な拮抗能を示す PP を選出、培美して Biofertilizer と

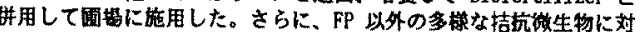

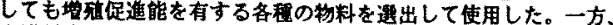

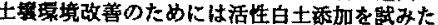

Biofertilizer 加区では、逨作後も 80X 以上という贾い雁病押制 率が得られ、そうか病による実用上の椇失を未然に防止することが てきた。Biofertilizer は拮抗菌の特界な培地として機能すること が明硥となった。

$3 F 208$ 植物病原性药状菌 Fusariug Solani のウィルス滕柆子

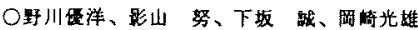

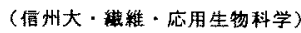

（目的）植物病原栍之の閏連が予想される婪色体外レプリコンのス クリーニングを行った䊅果、E. solani f. sp. robiniae SUF704に2 理類の2本鎮(ds)RNA汃梌出された。糸状菌でのdsRNAは、ウイルス㥞 柆子(YLP)のゲノムとして知られている。このdSRNAに関連するVLPを 棈繁しその性算について䁌へると其に、dsRNAのCDNA合成を行った。

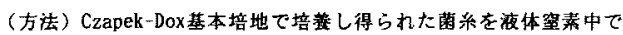

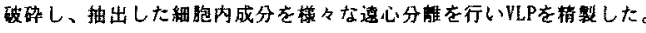

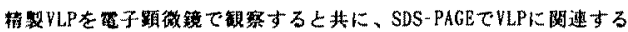
タンパク啠について分析を行った。cDNAの合成はdSRNAを10日水化 メチル水㒹て変性し、randow hexamertprimerに用いて行った。

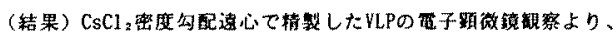
直径30n地球状粒子の存在汃明ら加になった。この分画のSDS-PACE 分析から38kDaの主要极タンパク質の存在汃示された。合成された CDNAのアガロースゲル西気泳動による分析から、は结完全镸のCDNA まで合成されている事が示された。覞在、得られたCDNAの㙁基配列 を分析すると共に、このVLPの伝道性について检郡している。

3F2a9 深海微生物の生産する圧力依存性のプロテァーゼ の精製と性貿 ○跉木聖子、鼻修一、加藤千明、 掘越弘媇 (海洋科技セ、深海微生物)

目的：深海底は高水圧下の世界であり、そこに成育してい る微生物はこうした摆境に適しして、特翼な性質を示すもの が多い。そこでそうした微生物が持つ深海底での適応機棈の 解明を目的として、有人潜水铜查船”しんかい6 500 " 奆 用いて採取した深海底泥から、深海微生物を単離し圧力依存 性のブロテフーゼを生産する株をスクリーニングし、その性 質を調べた。

方法と結果：日本海满深度 $6500 \mathrm{~m}$ の海底上り得られた サンブルがら、压力依存性のプロテアーゼ生産する株D S K25を分離し、本株の生理学的性質並びに生産されるプロ テァーゼの性質等の検討を試みた。その結果、DSK 25 株 は、Sporosarcina属に関連する菌株であることが推定され、 耐圧性を示した。又同株の生産するブロテァーぜは $400^{\circ} \mathrm{C}$ 、 pH 9 に至適のある分子量的 $44 \mathrm{KDa} \mathrm{I}$. の蛋白質で、高 水圧下にて影著に活性化された。

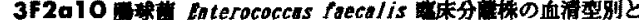

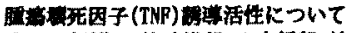

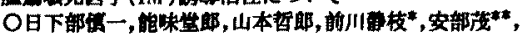
山口英世”"

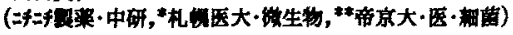

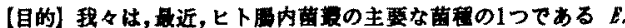

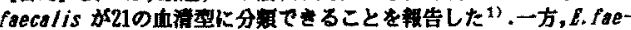

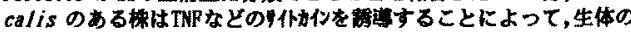

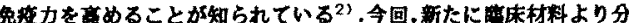

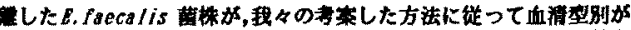

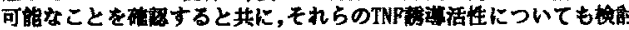

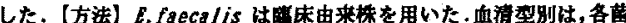

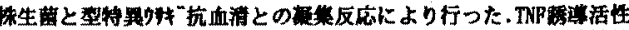

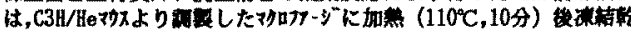

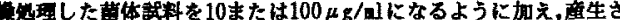

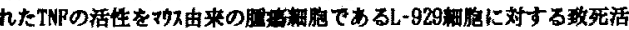

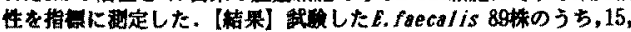

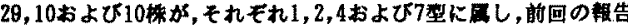

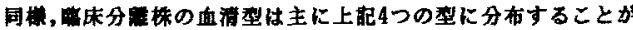
判つた.また、これら4つの型に属するそれそれ5〜8柇についてTHの

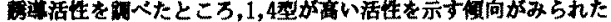

1) Maekawa,S., et al., Microbiol. Inmunol., 36, 671 (1992)

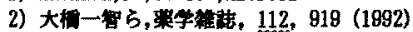

3F2a1 1 "Bacllius aneurinolyticus" の復活 ○信太 治'、高木広明!、門脇 清、阿部光子?

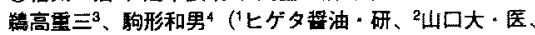

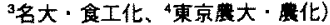

(目的) “Bacillus aneurinolyticus" は16S rANA塩基配列に基つく系 統挂から日，brevisと比較的近い関保にある”が、正式名として取り 扱われてはいない。そこで“B. aneurinolyticus”の化学分類学的性

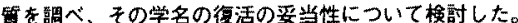

(方法) “B. aneurinolyticus” 23株について梌討した。G+C含量は HPLC法で测定した。DNA-DNA Hybridizationはマイクロプレート法 で行なった。また菌体虽白質の電気泳動バターンを解析し、さらに

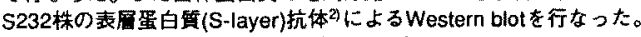
(結果) “B. aneurinolyticus" 23 株のG+C令量は41.1 43.4 mole\%

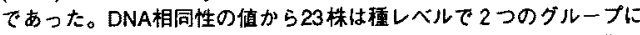
群別された。“B. aneurinolyticus” の原記数株を含む17株て構成さ れる1つのクルーブは “B. aneurinolyticus” として独立させること が妥当であると考えられた。また他の6株で構成されるグルーブは B. brevisから独立した“B. migulanum” と同董であることが習めら

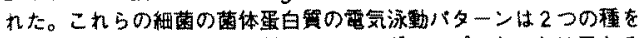
良く反映していた。また両種にB，brevisグループのものとは異なる 表層蛋白兵の存在が免废学的に矅められた。

1) FEMS Microbiol. Latt, 93, 167, (1992). 2) Microbiol. Immunot, 28, 841, (1984).

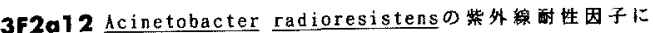
つ以

西村行正，○佐野元昭（東京理科大・応用生物）

1. 目的 Acinet,bacter radioresistuns

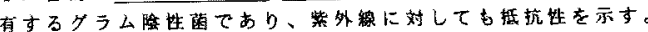
本研究はこれら抵抗性機撞を明ら加にることを目的として いる加、今回は紫外楾酎性因子の一つがフラスミドに存在す ることが明ら加になったので報告する。

2. 法及ひ結果 Acinetobacter radioresistens F0-1 侏 らナ゙ラスミドをアルカリ抽出法等により抽出し、柴外線に対 $し て$ 抵抗性 $の$ 低いAcinetobacter calcoaceticus 1 AN12087

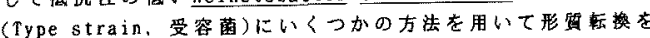

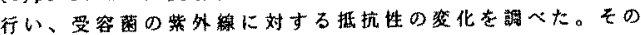

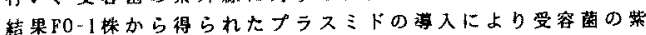

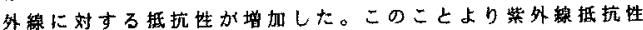
にはプラスミトが则与していることが明ら加となった。現在 得られた $3 つ$ づラスミトのいずれに抵抗性因子か子存在して いるか㛟郡中である。 
3F2a13 嫌気消化污泥中の主要メ夕ン生成細菌種の、脂質分析 による简便な推定 O西原正照、古賀洋介（産業医大・化学）

1.目的 消化污混などのメタン発醉系では、多種類のメタン生成 細菌と真正綶菌が共同して有機物の嫌気分解に関与している。この 系のメタン生成細囷の菌種と量をエーテル型脂質の楼成部品の分析 によって解析することを目的とする。

2. 万法拈よび結果 中温消化污泥 $\mathrm{A}\left(37^{\circ} \mathrm{C}\right.$ ，ステフェン廃液、固 定化、vss $=20000 \mathrm{ppm}) 、$ 高温消化污泥 B $\left(55^{\circ} \mathrm{C}\right.$, ビート、非固定化、

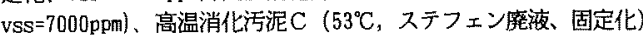
の3種の污泥加ら酸性Bligh \& Dyer法て脂質を抽出した後、アル力 リ処理によりエステル脂诈を分解してエーテル型極性脂貨を得た。 この極性脂質の糖とリンの定量により、污泥AおよびBではをれぞ れuss の75\%、30\%がメタン菌であると推定された。炭化水素鎖、 グリセロール骨格、極性頭部の構成䊰、リン酸を持つ極性頭部の程 類などの脂質構成部品の組み合わせの分析を行なってそれぞれの污 泥中の主琶メタン菌轷を同定した結果、いずれの污泥でもMethanos arcina属が優勢であったが、Methanothri属、Methanomicrobiacea e 科の菌も主要菌種として存在しており、污泥の種類によりその主 要菌種組成のバターンは異なっていた。

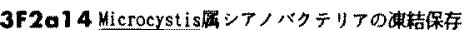

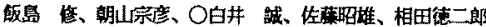

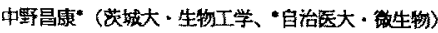

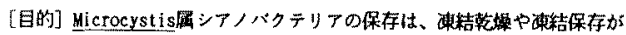

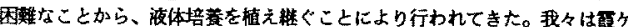

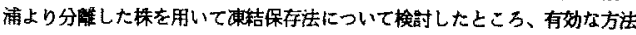
を見出したので瞃する。

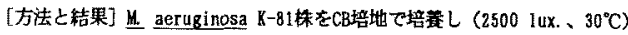
、刘数增殖期 (7日) 、定常期 (10日) およひ刘数增殖期の培美を保存培掌

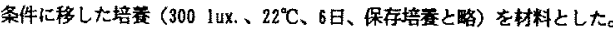

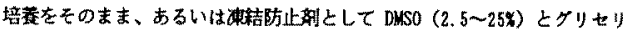

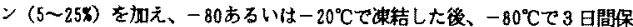

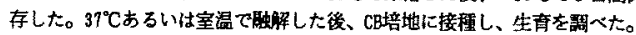

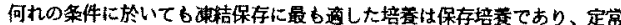

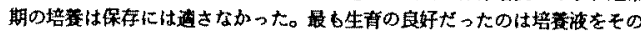

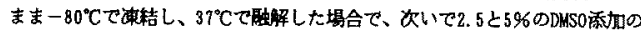

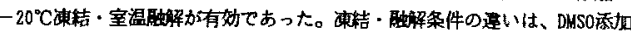

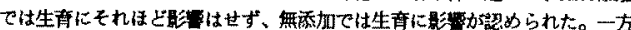

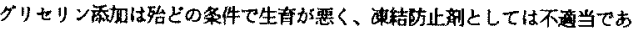
った。現在最期保存を梌詰しているが、これまでの結果でばー81株は 1 年閒、

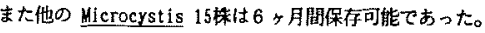

3F2p1 PHYLOGENETIC ANALYSIS OF T6S IDNA FROM TWO AEROBIC MAGNETIC BACTERIA.

- J. G. BURGESS, R. KAWAGUCHI, T. SAKAGUCHI AND T. MATSUNAGA. DEPARTMENT OF BIOTECHNOLOGY, TOKYO UNIVEASITY OF AGMICULTURE AND TECHNOLOGY.

GENOMIC DNA FROM TWO MAGNETIC BACTERIA, MAGNETOSPIRILLUM Sp. STRAINS MGT-1 AND AMB-1, WAS USED FOR AMPLIFICATION OF THE 16S IANA GENES (RDNA) BY THE POLYMERASE CHAIN REACTION. AMPLIFIED DNA BY THE POLYMERASE CHAIN REACTION. AMPLIFIED DNA
FRAGMENTS WERE CLONED, SEQUENCED (1408 BP) AND COMPARED WITH PREVIOUSLY REPORTED 16S RNA SEQUENCES FOR MAGNETOSPIRILLUM MAGNETOTACTIC. UM, MS-1 AND MAGNETOSPIRILLUM GRYPHISWALDENSE, MSR-1. STRAINS AMB-1, MGT-1 AND MS-1 FORM A MSR-1. STRAINS AMB-1, MGT-1 AND MS-1 FORM A DISTINCT GROUP IN WHICH THEY ARE MORE CLOSELY
RELATED TO EACH OTHER THAN TO STRAIN MSR-1. RELATED TO EACH OTHER THAN TO STRAIN MSR-1.
PHYLOGENETIC ANALYSIS OF THE 165 TDNA SEQUENCES INDICATED THAT THE TWO NEW MAGNETIC SPIRILLA, AMB1 AND MGT-1 LIE WITHIN THE ALPHA SUBDIVISION OF THE EUBACTERIAL GROUP PROTEOBACTERIA (1). FIVE REGIONS OF THE 165 GENE WERE FOUND WHOSE SEQUENCE WAS SPECIFIC TO MAGNETIC SPIRILLA. OLIGONUCLEOTIDE PROBES WERE USED TO DETECT MAGNETIC SPIRILLA USING THE POLYMERASE CHAIN REACTION.

1) KawaguchI, R., Burgess, J.G. and Matsunaga, T. (1992) Nucleic Aclds Research 20, 1140.
3F2p2 $16 \mathrm{~S} \mathbf{r}$ RNA監基配列に基つくく Rhizomonas 属及ひ

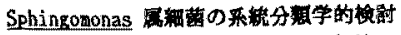

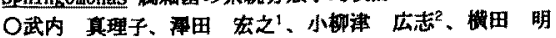

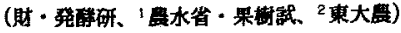

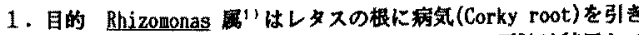

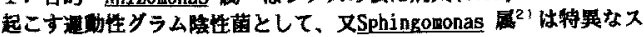

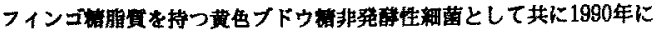

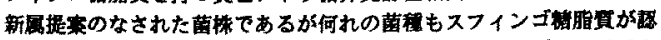

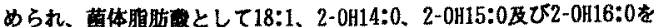
持ち3-0H脂胧酸性持たない。更に0-10、DNAのG+C含量80〜65\%と共通

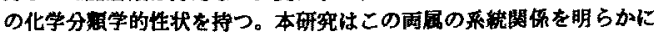
することを目的として 基程である-suberifaciens とSphingononas

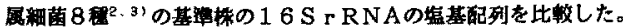
2. 方法 $16 \mathrm{~S}$ r RNAの塩基配列の決定は ${ }^{35} \mathrm{~S}$ を用いたジデオキ シ法を用い約 1400 缊基を決定しN J法により解折を行つた。

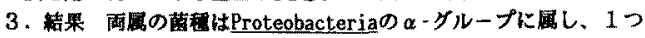
のクラスターを形成することが明らかになった。このことより我々は Sphingomonas 属とPhizomonas 属との続合を提案したい。

1) van Bruggen et al. Int. J. Syst. Bacteriol., 40, 175 (1990)

2) E. Yabuuchi et ai. Hicrobiol. Inmunol., 34, 324 (1990)

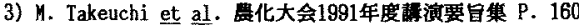

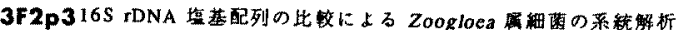

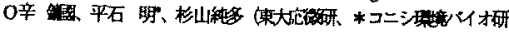

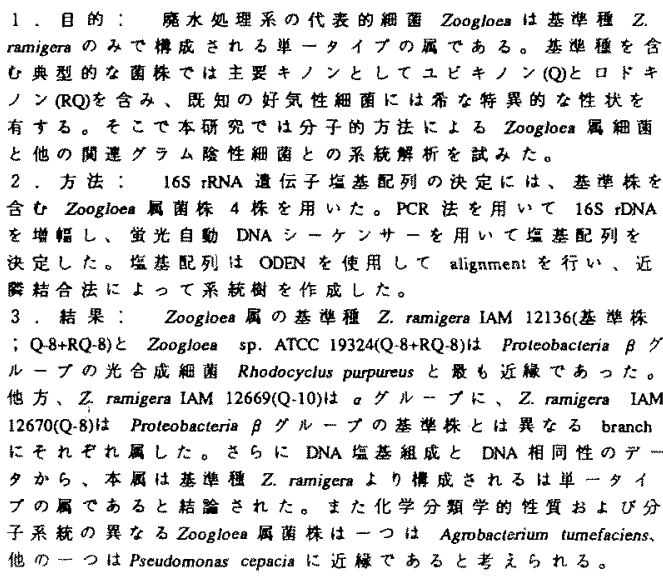

3F2p4 タフリナ, ブロトミケスの系統進化的位置 ○西田洋已、杉山純多（東大・応微研）

1) 目的 Taphrina, Protomyces はその特異な生活 環、形態より、Savile は高等菌類の祖先に最も近 い現存する菌類と位置付け、Cavalier-Smithは接合 菌類に入劢る方が良いとした。18S rRNA 塩基配列 比較により、Taphrina, Protomyces の系統進化的 位置を明らかにすることが目的である。

2) 方法 Taphrinaの基準種 Taphrina populina (CBS 337.55)、T. californica (CBS 374.39)、 Protomyces inouyei (IFO 6898) $\sigma$ 18S rRNA gene をPCRにより增幅し、精製泚縮の後、增揊座物そ のものの塩基配列を決定した。既知の塩基配列と比 較し ODEN, PAUPを用いて系統榯を作成した。 3) 結果 Taphrina, Protomyces は極めて近い関係 にあり、Taphrina, Protomyces が形成した系統群 は担子菌類、子葴類の系統群とは独立した新系統 群を形成し、高等菌類の進化上、担子菌類と子墐菌 類を結び付ける系統進化的位置を占めた。 
3F2p5 Flavobacterium-Cytophaga complex O系統分類 O中川䓠好，山里一英（東大·空微研）

1. 目的 Flavobacterium 属とCytophaga 属は，共にタラム陰性の桿菌 で，通常の分類学的性状だけでなく化学分類学的性省によっても䧕別が 图難であり， Flavobacterium-Cytophaga complex と呼ばれている.また 先に我々は，Cytophaga 属は系統的に多様であり1つの分数群としてまと まりがないことを報告した。本研究では，16S rRNA の塩基配列を決定す

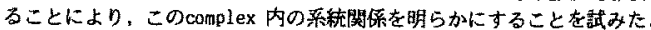

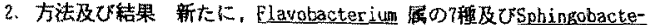

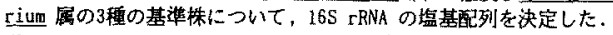
Flavobacterium-Cytophaga complex は，大きく120系絰鲜に分かれてお ク.MK-6 の菌種と、MK-7 の菌種は互いに新れていた。 Cytophaga 属は

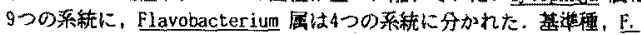
aquatile とR. branchiophilum はMK-6 で陸生のCytophaga といつのクラ

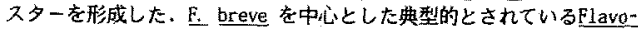
bacterium species は1つのクラスターを形成し，Fａquatile とは雄的 ていた. E. odoratum はどのタルーブも属さなかった. Sphingobacteriu species 壮独立したクラスターを形成しており，本属の存在仙系 統的にも明らかとなった. F. thalpophilum 及びF. yabuuchiae は。 Sphingobacterium のクラスターに含击れた. Cytophaga, Flavobacte「ium, Flexibacter species は, 多くのクラスターにおいて混在してお

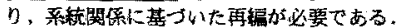

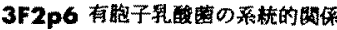

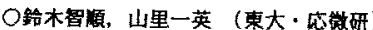

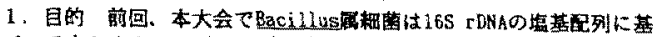
ついて大きく6つのダルーブに分かれ、その内の1つ(グルーブ6)

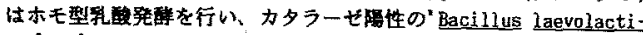
cus'ど 'Bacillus racemilacticus'、及びカタラーゼ降性の Sporolactobacillus inulinusからなることを報告した。今回は、より䛨細 な系統を明らかにすることを目的として、さらに多くのカタラーゼ婹

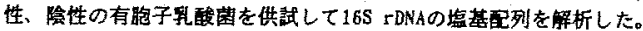

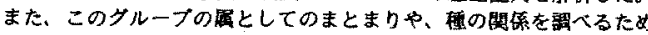
に、DNA-DNA 交䑾を行った。

2. 方法及U大結果 $\mathrm{PCR}-{ }^{35} \mathrm{~S}$ sequence法に上り約 1500 bpの16S IDNA

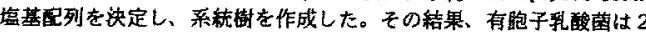

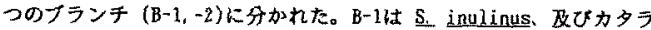
一七隐性("Sporolactobacillus Laevas", "Sperolactobacillus cacemicus")、淂住("B. laevolacticus", "B. tacemilacticus, "B.

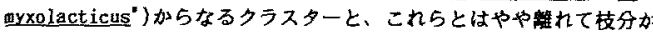
れしているカタラーゼ淂性の゙B，racemilacticus" M5から形成されて いた。B-2はカタラーゼ陵性やある "Stocolactobacillus dextrus"

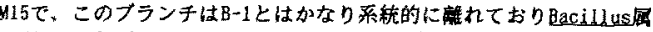
のダーフフ1 (Bacillus subtilus group)の中に位置していた。

3F2p7 Proteobacteria $\alpha \xi^{\prime}$ にー7属する光合成細菌の系統 一光含成細菌と非光合成細菌の系絰関保 ○川峈浩子，星野八洲雄 ，平田愛子，山里一英

(東大·応微研、都立大，理）

目的) Photosynthetic purgle nonsulfur bacteria (Rhodospi-

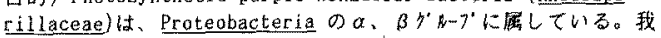

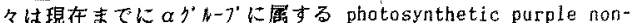
sulfur bacteria に2uて165 rRMA の塩基配列の解析を行い、系 統的にdiverseであることを明らかにしてきた。本研究では、さら

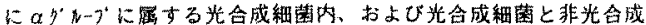
紐菌との系統閿係を明ら加にすることを武みた。

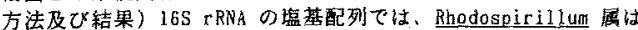

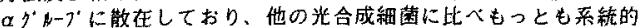

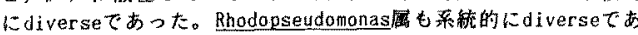
るか、Rhodopseudomanas blastica を除いて一つの系統群を形成 していた。。それぞれの風内で非光合成細圈との類緣性が㑇めら h. Rhodospirillum fulvum 徒走磁性租菌 Magnetospirillum magnetotacticum と近緑であり、Rhodobacter cluster の中心。

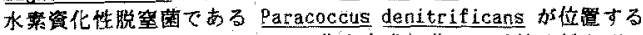
一とが明らかになった。さらに非光合成細落との系統関係を明ら 加にするために、新たなbranchを形成する光台成細蔽の存在を明 ら加に、これらの系梳関倸について赫告する。
$3 F 2 p 8$ Rhizobiaceas 及ひ関連細菌の分子系就

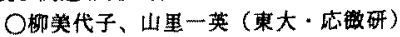

【目的】Rhizobiaceae 及びその関連紐菌の采統関係を明らか にするために、16S rRNA遭伝子の盐基配列を決定した。 【方法と結果】2扸のPCRに上り管光ラベル・ブライマー配列

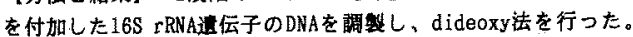
DNAシーケンサーで約1300の塭基配列を決定し、参考菌株を含め てN-J法により解析を行つた。Rhizobiaceae の3属、Rhizobium, Agrobacterium, Phyllobacterium はOchrobactrum, Mycoplana (M. dimorpha, M.ramosa), Brucella abortus, Rochalimaea quintana, Bartonella bacilliformis と1つのfamilyに相当する と考えら九るクラスターを形成したが、Bradyrhizobiumは含ま れなかっだ。.Rhizobium はAgrobacteriul, Phyllobacterium のbranchk厷く㬴在していた" . M. bullata, M. segnis は Pseudomonas diminuta とともに1つのクラスターを形成した。 Agrobacterium yellow group 33 株 Chromobacterium lividum NCTC 10590, 10591はRrythrobacter longus とともに1つのクラ スターを形成した。

1) Yanagi and Yamasato, FEMS Microbiol. Lett., (1993) in press.

3F2p9 分子的方法に上る不完全菌稹Penicillium、Gensmithia、 Meriublaと閶連テレオモルフす系統解析

○吉村影子、杉山純多（果大·废敞研）

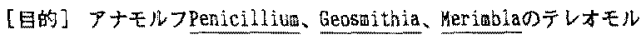
フはT'alaronyces、Eupenicilliu等の諸展と関係し、分颣体系上不整子

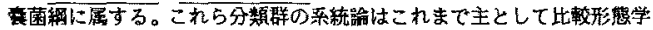
的方法から諭しられてきたが、本研究は分子進化からこれらの系䋨を明 らかにすることを目的としている。

[方法] Geosmithia、 Merimblaと関連テレオモルフ3株、アナモルフ2

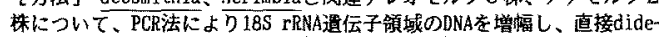
oxy法で塩基配列を決定した。これら5株とPenicilli圈等の既知塭基配

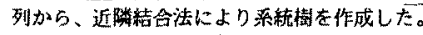

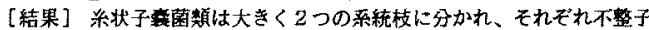

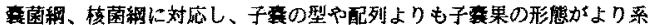
統を反映していることがわかった。 Talaromyces bacillisporus、Ha五i-

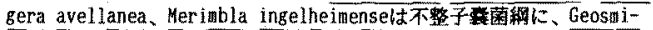
thia lavendula

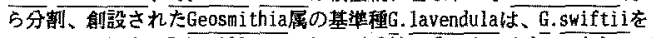
アナモルフにもつT.bacilliporusとは别系新に分かれ、 B.lavendulaの

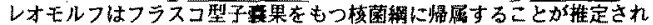

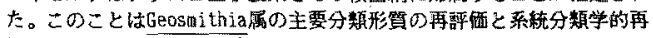
糄が必須であることを示㖫する。またTaralomyces、Hawigera、Merimbla の系巯関保についても考察する。

\section{F2p10}

$$
\begin{aligned}
& \text { Acidiphilium 属細菌の分子系統 } \\
& \text { ○平石 明、若尾紀夫* } \\
& \text { (コニシ摆境バイオ砑、"岩手大展) }
\end{aligned}
$$

且的Acidiphilium 属稩菌は好酸性の好気性従属栄菱細菌である か、最近、本属菌種が好気条件下でバクテリオクロロフィルa合 成することが判明しだ。本研究では16S rRNA道伝子の盐基配列 を解析することにより、本属内菌程同士の系繶関保および他の好 気性バクテリオクロロフィル合有細菌、好酸性細菌との系統関係 を明らかにすることを試みた。

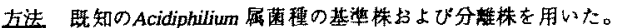

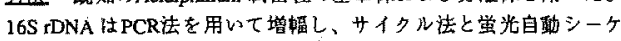

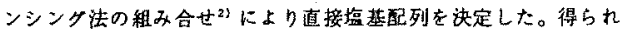
た約1300bpの配列に基つき近榙合法により系統榯を作成した。

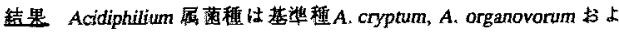
び分離㧣が属寸るクラスターとA. rubrum，A. angusaumによって形

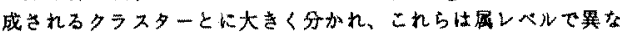
るもの上考之られた。好気性光合成稩菌Erythrobacter,Raseobactu, Methylobacteriumなとととはいずれも系統的に蜼れていた。

1) Shiba ex al. submitted.

2) Hiraishi, A. Lett. Appl. Microbiol. 15:210 (1992) 


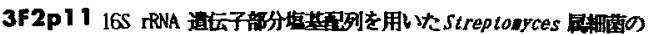

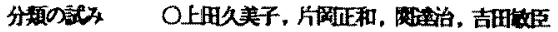

(攺大 $\cdot I \cdot I C B$ iotech)

1. 目的数值分頪法が用いられてきたStreptonyces 属䊩落のこれまでの

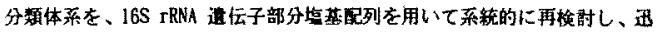
速同定法の精立を目的とした。

2. 方法 Streptonyces 属細菌について、165 rRMA道伝子の 158 278 番

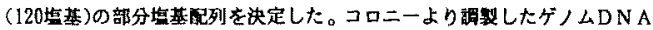

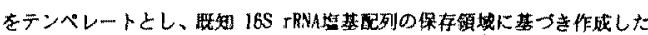
プライマーを用いＰＣRを行った。その座物を入エキリヌクレアーセて 消化することにより一本镇とし、7-deaza-guanosine を用いたdideoxy法に

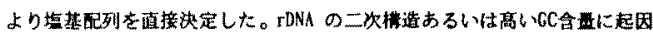
するスタッキングを解消するために、反応液中にS S Bを加えた。

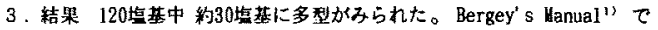
Category I /Clasterlに屈する10棰と CategoryNに䖪する s.champavatii

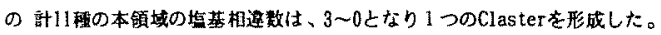

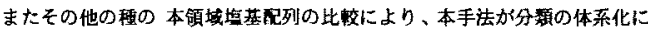
奇与することが明かとなった。

1)Bergey's Hanual of Systematic Bacteriology Yol. 4 (1989)

3F2p1 216S IRNA をターゲットとするオリゴヌクレオチドプ ローブを用いた Bifidobacteriu成の㮔の同定 ○山本隆晴、棓富正己、田中隆一郎（ヤクルト中研）

具的 Bifidobacterium 属の種の同定は主として、模分解性 桨など表現形質を基にした方法により行われている。しかし 二の方法により、食品萁便を対像とした研究において多く の菌を同定主るには、かなり多くの時間亡労力を必要と娄る ため、より武速で簡便な同定法が害まれていた。气て我名 は、系統行類学の指標の一つてあり、菌体当たりのコピー数

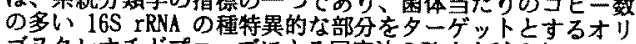
ゴヌクレオチドプロープによる同定法の確立を試みた。 方法・結果 Bifidobacterium 属 8 菌種の type strain $16 S$ rRNA の部分シークエンスを、逆軽写睹蓄を用いたdi deoxy 法により行い、種特異的な部分を抽出し、B. adolescentis, $B$. bifidum, $B$. breve, $B$. infantis, $B$. longum の5菌種をそれそれ同定するためのオリコヌクレオチドフ ローブを合成した。1\% formaldehyde て固定した菌体 (同 species 7 strains (異なる species 54 strains) らのプローブとの hybridization を検討したところ、人や 多の生物由来の菌種に対して cross hybridization を示守 プローブもあったか、人の腸内から検出される菌種に対して は完全な種特異性を示した。また、非アイソトーフ的同定法 についても検討した。

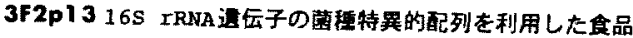
中の細菌の湌出と同定

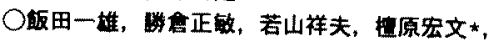
阿部章夫**，川原一芳**，松井英則** （紀文蚙品，*北里大・渠，**北里研）

1 目的細菌間で保存されている16S rRNA造伝子を指㜔と して食品中の污染菌 (大腷菌群及びサルモネラ) の高感度かつ 迅速な検出同定を嘼みた。

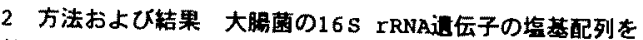
基にして，広く腸内細菌に保存されると思われる領域からプ ライマーを合成した。これを用いて染色体DNAを铸型とし たPCR反沈によりnterobacter屈，Rlebsiella蚛など 数菌種の16S rRNA逗伝子䄪900 bpを增愊した。次にこの增 愊したDNAの䝷基配列を決定した。得られた塩基配列より菌

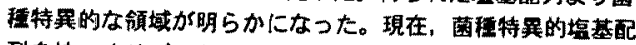
列を持つオリゴヌクレオチドプローブを合成しリバースドッ トブロットハイブリタイゼーション法による迅速な菌椎判別 法の検璟を行っている。
3F2p1418SリボゾームRNA塩基配列に基づく担子菌醉母フ ロバシジウム科とテリオスボア形成醉母群の分子系統 ○徐望義、杉山純多 (東大·応微研)

【目的】担子菌醉母フィロバシジゥム科とテリオスポア形成 醂母群の主要藩種について系統進化の研究に有效な18Sりボ ソームRNAの全塩基配列を決定、比較解析し、各分類群の系 就学的位置を明ら加にすることを試みた。

【方法】 PCR法により增幅した18S rRNA geneの塩基配列は直

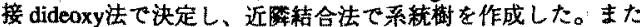
プートストラップ法を用いて各系統枝の統計学的信頼度を算 出した。

【結果】決定した各約1750塩基に上り系統樹を作成した結果、

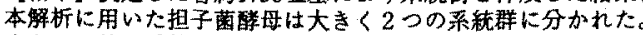

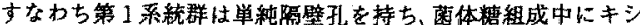
ロースを久く Rhodosporidium toruloides, $R$, dacryoidum, Kondoa malvinella, Leucosporidium scottii, Erythrobasidium hasegawianum を含み、一方ドリボア型隔壁孔を持ち、キシロースを含有する Cystofilobasidium capitatum, L. lari-marini, Mrakia frigida, Filobasidiella neoformans, Filobasidium floriformeなどは第 2 系統群を形 成した。以上の結果から担子菌醉母フィロバシジウム科とテ

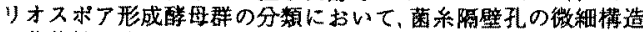
や菌体精組成中キシロースの有無はテリオスポア形成能や担 子器の形堭より系繶を反映している形質であると考えられだ。

3F2p 15 Genera Citeronyces, Clavispora, Pachysolen and Arxio-

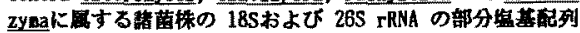

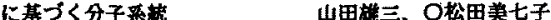

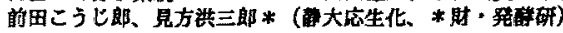

1 目的 Genera Citeromyces and Pachysolen it genus Hansenula

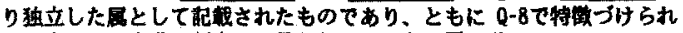

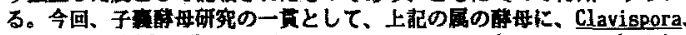
Arxiozymak

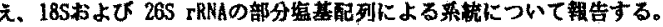
2 方法および結果 Genera Citeromyces, Clavispora, Arxiozyea, Pachysolen, Pachytichospora and Trigonopsis. P.anomalak属する菌

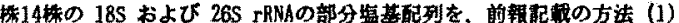
にて、求めた。18S rRNAのposition 1451-1618の颃域てのfinger print segnent の塩基配列は, P. anomala では AAUAA, C.matritensis では ACUAA、および、P.tannophilus では ACUAA なる Debaryonyces䍿の5文 字、Cl.lusitaniae Cは UGAなる Letschnikowia型の3文字、A.tellu-

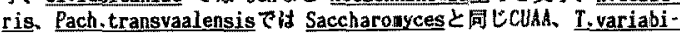

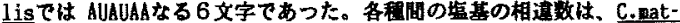

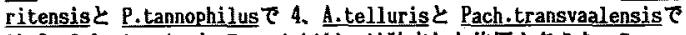
は 3、C.Iusitaniaeと T.variabilis 独立した位直を与えた。P.ano-

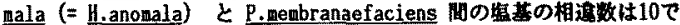

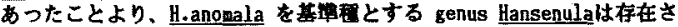
せるべぎあると結偷された。26S rRMAついても述へる。1）Y. Yamada and H. Kawasaki, J, Gen. Appl. Microbiol., 35, 173 (1989).

3F2p16 Apiculate yeastsの18S および 26S rRNA の部分垍基配列に 基づく分子聚梳

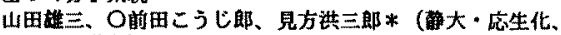

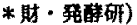

1 目的 演者らは、さきに、Q-6 をもつ apiculate yeasts の 18 S お

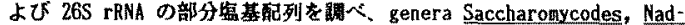
sonia and Hanseniaspora 3属の存在は努当だあることを示した。ただ、 genus Hanseniaspora は、分子系莸学的に、2系列よりなり、round ascosporesをもつ3 3 究、 genus Kloeckeraspora Niehaus emend. へ移 した $(1,2)$ 。今回は、不完全猎母 genus Kloeckera および Q-9 で特政

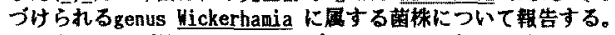

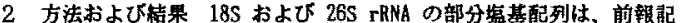

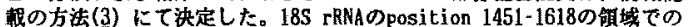
finger print segment $の$ 留基配列 (S.cerevisiae $\sigma_{\text {position 1488-1491) }}$ は. K.africana. K.corticis 2 株. K.javanica var.javanica 2 株,

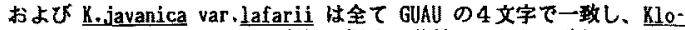
eckeraspora Niehaus end. (2) に属する苗株のそれと一敏した。一方。 U.fluorescens $の$ finger print segventの監基配列は UAUAUA $の 6$ 文字 であったことより、Q-6 をもつapiculate yeasts $(1,2)$ とは、その系期

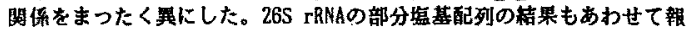
告する。 1) Y. Yamada, K. Maeda and I. Banno, J. Gen. AppI. Microbiol., 38(6), 1992, in press. 2) Y. Yanada, K. Maeda and I. Banno, Bull. JFCC, 8(2), 1992, in press. 3) Y. Yamada and H. Kawasaki, J. Gen. Appl. Kicrobiol., 35, 173 (1989). 


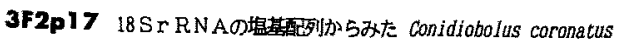

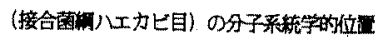

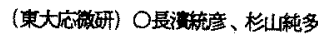

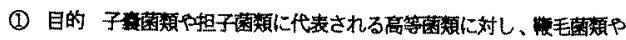

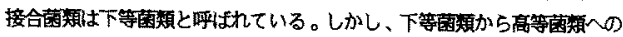
趛化の道すしは未だ明らかではない。そこて我っは、特に接合圈類から离 等蔽への進化の上で重要な位霍を占めると考えられる、八エカピ目 Conidiobolus coronatus $018 \mathrm{~S}$ r RN Aの壏基配列を決定し、それ5の 柔较学的位量を西そうと考えた。

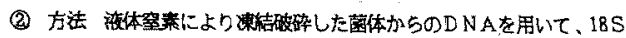
IDNA領域をPCR塔福し、アガロースゲルーガラスビーズ法により棈 慗、Sequenase

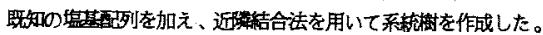

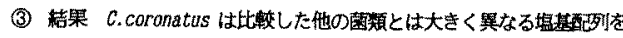
持つにも関わらず、Mucor racemosus (接合菌粠ケカビ目)とクラスターを 形成した。また、それらたジ゙カビ類 Blastocladiella emersonii を加

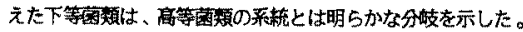

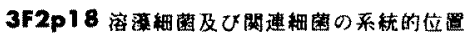

○細金真由美、池上秦子、黑田伸郎*、片山基子"*，

令石葆**, 山里一英

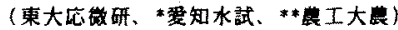

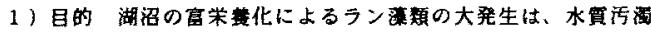

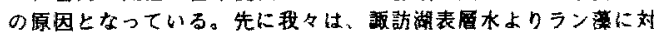

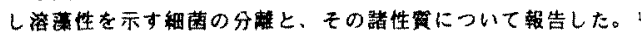

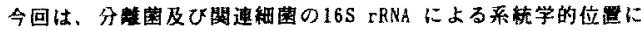
ついて模討を行った。

2)方法と結果 $16 \mathrm{~S}$ rRNA 造伝子は 2 段陵のPCRによりシーヶ ンス用フライマー列を付加して增幅し、450-750 bp のDNA断片 として整整した。dye-primer 角いた dideoxy 法を行い、ABI 373A DNA シーケンサーを用いて、約 1300塩基の要列をを決定 し、NJ法により䑫析を行った。

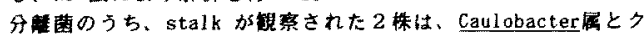
ラスターを形成した。これらは、C. fusiformis, C. bacteroides

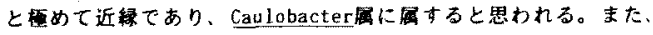
appendage を持っ 3 格は、 Blastobacter natatorius とクラスタ

一を形成し、Caulobacter クラスターとは大きく㸕れていた。

1)大谷ら 日本㖘芸化学会大会境演要旨集 (1992) P272 